\title{
What is the Impact of International Remittances on Poverty and Inequality in Latin America? ${ }^{1}$
}

\author{
Pablo Acosta \\ (Corporación Andina de Fomento) \\ Cesar Calderón, Pablo Fajnzylber and Humberto Lopez \\ (The World Bank)
}

\begin{abstract}
Workers' remittances have become a major source of income for developing countries. However, little is still known about their impact on poverty and inequality. Using a large cross-country panel dataset, we find that remittances in Latin American and Caribbean (LAC) countries have increased growth and reduced inequality and poverty. These results are robust to the use of different instruments that attempt to correct for the potential endogeneity of remittances. Household survey-based estimates for ten LAC countries confirm that remittances have negative albeit relatively small inequality and poverty reducing effects, even after imputations for the potential home earnings of migrants.
\end{abstract}

Keywords: Remittances, growth, inequality, poverty, Latin America.

World Bank Policy Research Working Paper 4249, June 2007

The Policy Research Working Paper Series disseminates the findings of work in progress to encourage the exchange of ideas about development issues. An objective of the series is to get the findings out quickly, even if the presentations are less than fully polished. The papers carry the names of the authors and should be cited accordingly. The findings, interpretations, and conclusions expressed in this paper are entirely those of the authors. They do not necessarily represent the view of the World Bank, its Executive Directors, or the countries they represent. Policy Research Working Papers are available online at http://econ.worldbank.org.

\footnotetext{
${ }^{1}$ Paper forthcoming in Word Development. We thank four anonymous referees for valuable comments, Maria Soledad Martinez Peria for providing us with the data on remittances, and Guillermo Beylis and Nam Suk Kim for valuable research assistantship.
} 


\section{INTRODUCTION}

Flows of workers' remittances have become a major source of external finance for developing countries. During the past ten years, the growth of remittances has outpaced that of private capital flows and official development assistance. In 2004, remittances to developing countries totaled about US\$144 billion, and were equivalent to about 5 percent of imports and 8 percent of domestic investment. They reached almost 90 percent of FDI and were larger than official flows and private non-FDI flows. ${ }^{2}$ Remittances are especially important in Latin America. With flows of US\$40 billion in 2004 and 27 percent of all remittances to developing countries, Latin America is currently the top remittance receiving region in the world. With an annual growth rate of 15 percent over the past 15 years, Latin America has also experienced among the highest rates of growth in remittances inflows, trailing only East Asia.

Given the magnitude, stability and potentially beneficial macroeconomic effects of workers' remittances, the growing interest in the topic among development practitioners should not come as a surprise. Yet, very little is still known about the poverty and inequality impact of these flows. Microeconomic evidence based on household survey data suggests that remittances are generally associated with reductions in poverty, ${ }^{3}$ but they may increase or decrease income inequality depending on the initial level of migration of sending communities. ${ }^{4}$ Several of the existing studies, however, are based on rural and village-level data ${ }^{5}$ and only one focuses on a nationally representative survey for a Latin American country.

At the cross national level there are, to the best of our knowledge, only two recent studies (Adams and Page, 2005, and World Economic Outlook, 2005) that have looked at this issue. Both of them find that countries that receive remittances have lower poverty levels. Adams and Page find that a 10 percent increase in per capita remittances would lead to a 3.5 percent decline in the share of people living in poverty in the corresponding country. World Economic Outlook (2005), on the other hand, finds that a 2.5 percentage point increase in the remittances to GDP ratio is associated with a 0.5 percentage point decrease in poverty.

This paper contributes to the literature on the effects of remittances on poverty and inequality along several dimensions, using both aggregate country-level data and nationally representative household surveys for ten Latin American and Caribbean (Latin American hereafter) countries. First, we complement previous cross-country studies by using an econometric approach that allows us to estimate the separate impact of remittances on each of

\footnotetext{
${ }^{2}$ See Global Economic Prospects (2006).

${ }^{3}$ See, among others, Adams $(2004,2006)$ respectively on Guatemala and Ghana, Lopez-Córdova (2005) and Taylor et al. (2005) on Mexico, and Yang and Martinez (2006) on the Philippines.

${ }^{4}$ This is the conclusion reached by Stark, Taylor and Yitzhaki (1986) and Taylor, Mora and Adams (2005) using data from rural Mexico. Other papers, however, have concluded that remittances have the effect of increasing income inequality: see for instance Adams (1989, 2006) on Egypt and Ghana, respectively, Barham and Boucher (1998) on Nicaragua, and Rodriguez (1998) on the Philippines.

${ }^{5}$ The exceptions are the papers on the Philippines, Ghana and Guatemala. The data used by Lopez-Córdova (2005) is also nationally representative but it is aggregated at the municipal level.
} 
the two potential drivers of poverty: ${ }^{6}$ average income growth and income inequality. This is important because as noted in World Economic Outlook (2005) estimates of the poverty effects of remittances based on regressions that control for per capita GDP and indexes of income inequality - such as those in Adams and Page and the World Economic Outlook - can be substantially biased as they miss the effects that operate through changes in average income or inequality.

Second, unlike previous cross-country studies we introduce some degree of country heterogeneity in the analysis. Thus, in our regression estimates we allow the impact of remittances on growth and inequality to be different for Latin American countries. Moreover, when mapping the estimated effects of remittances on growth and inequality on the corresponding impact of remittances on poverty, we take into consideration each country's initial level of inequality and development. ${ }^{7}$

Third, in contrast to previous cross-country analysis of this topic, we exploit in our estimates the panel nature of the data, thus allowing for the possible existence of fixed effects, motivated for instance by time-invariant unobserved country characteristics. Moreover, we perform our estimation in a dynamic panel framework, using both internal and external timevarying variables to instrument for remittances. We are able to introduce some of these statistical refinements thanks to the larger availability of data on inequality and growth data, in comparison with the limited samples that are available in poverty databases.

Fourth, using household survey data for ten Latin American countries with quite different migration patterns, we estimate the effects of discrete and marginal changes in remittances on household income inequality. In this respect, we first make the assumption that remittances operate as exogenous transfers by migrants, and thus consider the counterfactual scenario of changes in remittances without changes in migration.

Fifth, to complement the above estimates, we compare observed levels of poverty and inequality with the levels that would prevail in the counterfactual scenario of no-migration and no-remittances. We pursue this alternative on the basis of the more realistic assumption that remittances are a potential substitute for home earnings, which we impute based on samples of non-migrant households, in a selection-corrected estimation framework.

To anticipate some of our main results, our cross-country estimates suggest that remittances have a positive and statistically significant effect on growth that is of a similar magnitude in Latin America and in the rest of the world. This result is robust to the use of different instruments (internal and external) for the indicator of remittances. The evidence on the impact of remittances on inequality, however, is somewhat more mixed. For the typical country in the global sample we find that remittances tend to increase the level of income inequality. On

\footnotetext{
${ }^{6}$ In what follows all references to poverty should be understood as references to headcount poverty. The qualitative results of this paper, however, can be extended without loss of generality to the other two Foster, Greer and Thorbecke (1984) poverty measures (the poverty gap and the squared poverty gap).

${ }^{7}$ As argued by, among others Lopez and Serven (2006), the impact of growth and changes in inequality on poverty reduction depends on the country's initial level of inequality and development. In other words, even if remittances had the same impact on growth and inequality in every country they could still have a different impact on poverty levels.
} 
the other hand, we find that in the typical Latin American country remittances slightly reduce inequality or leave it unchanged depending on the particular specification.

By combining the results on the effects of remittances on growth and inequality with initial country conditions, we find that remittances generally lower poverty. However, the elasticity of poverty reduction with respect to remittances differs significantly by country. For instance, we find that depending on the countries' different initial levels of inequality and development, the percentage reduction in poverty for a 10 percent increase in the ratio of remittances to GDP could range from about .04 percent (poorer countries) to .5 percent (richer countries). Equivalently, considering than in the Latin American region remittances represent on average 4.9 percent of GDP, these results would imply that for every percentage point increase in the remittances to GDP ratio, poverty in the typical Latin American country would fall by about .37 percent.

As for our micro-econometric results, we find that in 8 out of 10 countries the observed Gini coefficient of per capita household income is smaller than the Gini that would prevail in the absence of remittances, for given non-remittances income. The changes, however, would be generally small, averaging less than 2 percent of the initial Gini ${ }^{8}$ for the countries in which inequality is estimated to decrease as a result of remittances, and less than 0.2 percent in those in which it increases. For marginal changes in remittances, we find that in 6 out of 10 countries inequality would increase as a result of small ceteris paribus increases in those flows of income, a result that is driven by the fact that remittances are generally more unequally distributed than non-remittances income and with a few exceptions they have a high correlation with total income.

When imputing non-remittances income in the counterfactual scenario of non-migration, our results suggest that in six countries migration and remittances have an even less equalizing effect. However, in the other four countries, where migrants tend to come from the upper segments of the income and educational distributions, the evidence is quite the opposite, with migration and remittances now reducing inequality much more than before. As for the simulations of the poverty effects of remittances and migration, they show that attempts to estimate the poverty-reducing effect of remittances based only on the analysis of observed nonremittances income grossly over-estimate those effects. On average, when moving from the noremittances to the non-migration counterfactual scenarios, the reduction in extreme poverty as a result of migration and remittances falls from 14 to 3 percent and that in moderate poverty from 8 to 3 percent. Thus, the results based on micro data also indicate a moderate impact of remittances on poverty: on average for the 10 countries in our sample extreme and moderate poverty would fall by respectively 0.37 and 0.4 percent for every 1 percentage point increase in the remittances to GDP ratio, a finding that is surprisingly close to the one obtained on the basis of cross-country regressions.

The rest of the paper is structured as follows. In section 2 we review the empirical strategy adopted in our cross-country estimates, including a discussion on the links between changes in poverty, growth and inequality, and a summary of the challenges involved in the estimation of a dynamic panel data models with country specific effects. Section 3 presents the

\footnotetext{
${ }^{8}$ Or about 1 percentage point for a typical Gini of .5 .
} 
basic characteristics of our cross-country data and summarizes the corresponding empirical results. Section 4 describes the empirical strategy adopted in the micro-econometric section of the paper. Section 5 presents the household survey data used in the paper and the respective empirical results. Finally, section 6 offers concluding remarks.

\section{CROSS-COUNTRY EMPIRICAL STRATEGY}

\section{(a) Poverty, growth, and inequality}

In this section we use simple techniques to show that under fairly general conditions the degree of poverty in any given country can be expressed as function of two factors: the average income level of the country and the extent of income inequality, so that to the extent that remittances raise income levels or lower income inequality they will also contribute to lower poverty.

Formally, consider the Foster, Greer and Thorbecke (FGT) (1984) family of poverty measures, given by

$$
P_{\alpha}=\int_{o}^{z}\left[\frac{z-x}{z}\right]^{\alpha} f(x) d x
$$

where $\alpha \in\{0,1,2\}$ is a parameter of inequality aversion, $z$ is the poverty line, $x$ is income, and $f($. is the density function of income. When $\alpha=0$, (1) reduces to the familiar headcount ratio, which measures the share of the population below the poverty line $z$. When $\alpha=1$, it measures the poverty gap and when $\alpha=2$, it measures the squared poverty gap.

Assume now that income follows a $\log$ normal distribution ${ }^{9}$ (i.e. $\log x$ is normally distributed). In that case, Lopez and Serven (2006) show that (i) $P_{\alpha}=P_{\alpha}(Y, G)$ where $Y$ and $G$ denote the average per capita income level and the Gini index respectively; (ii) $\gamma=\frac{Y}{P_{\alpha}} \frac{\partial P_{\alpha}}{\partial Y}$ and $\phi=\frac{G}{P_{\alpha}} \frac{\partial P_{\alpha}}{\partial G}$ can be expressed as functions of $z, Y$ and $G$; and (iii) $\gamma<0$ and if $z<Y$ (i.e. if the poverty line is smaller than average income levels) $\phi>0$. Moreover, when Lopez and Serven (2006) compare the theoretical quintile shares according to a log-normal distribution with their empirical counterparts using data from 794 household surveys they find that the log-normal approximation fits the empirical data extremely well, to the point that they formally test the null hypothesis that income follows a log normal distribution are unable to reject such null hypothesis.

\footnotetext{
${ }^{9}$ Attempts to model the size distribution of income using a log normal distribution have a long tradition in the economics literature, dating back to Gibrat (1931). Gibrat (1931) provided a theoretical justification for this particular functional form and presented empirical evidenced indicating that the log normal distribution offered a good empirical fit to the observed distribution of income. Gibrat's work was followed by other works extending his basic theoretical framework and offering additional empirical evidence (Kalecki, 1945, Rutherford, 1955).
} 
With these elements in mind, a change in poverty due to a change in remittances (which we will denote by $R$ ) can be expressed as:

$$
\frac{\partial P_{\alpha}}{\partial R} \frac{R}{P_{\alpha}}=\frac{\partial Y}{\partial R} \frac{R}{Y} \frac{\partial P_{\alpha}}{\partial Y} \frac{Y}{P_{\alpha}}+\frac{\partial G}{\partial R} \frac{R}{G} \frac{\partial P_{\alpha}}{\partial G} \frac{G}{P_{\alpha}},
$$

or

$$
\frac{\partial P}{\partial R} \frac{R}{P}=\frac{\partial Y}{\partial R} \frac{R}{Y} \times \gamma+\frac{\partial G}{\partial R} \frac{R}{G} \times \phi
$$

According to equation (3), the impact of a change in remittances, $R$, on poverty will depend on: (i) the impact that $R$ has on growth; (ii) how growth is translated into poverty reduction; (iii) the simultaneous impact that $R$ has on inequality (as measured by the Gini coefficient), and finally (iv) how inequality changes are translated into poverty reduction.. Clearly, the usefulness of expression (3) for empirical work still requires knowledge about how remittances translate into income growth and changes in income inequality. We discuss this issue next.

\section{(b) The impact of remittances on growth and inequality}

In order to estimate the links between remittances and growth in the data, our empirical strategy is based on the addition of a measure of remittances to an otherwise standard empirical growth regression:

$$
\left(y_{i t}-y_{i t-1}\right)=\delta y_{i t-1}+\omega^{\prime} x_{i t}+\beta r_{i t-1}+v_{i}+v_{i t},
$$

where $y$ is the log of per capita income, $r$ is a measure of remittances, $x$ represents a set of control variables other than lagged income, which we shall discuss shortly, $v_{i}$ is a countryspecific effect, and $v_{i t}$ is an i.i.d. error term.

According to (4), growth depends on initial income, remittances and current and/or lagged values of the control variables. Our primary focus is to assess the nature and magnitude of the estimate of $\beta$ in equation (4). If remittances have a positive impact on growth we should find $\beta>0$, whereas if they have no impact on growth we might find $\beta=0$.

One limitation of the previous specification is that it imposes the same slope $\beta$ for all the countries in the sample. To both allow for some heterogeneity and test whether the basic results would hold for a Latin American sub-sample the empirical section considers the following variation of (4):

$$
\left(y_{i t}-y_{i t-1}\right)=\delta y_{i t-1}+\omega^{\prime} x_{i t}+\beta_{1} r_{i t-1}+\beta_{2} r_{i t-1} \times l a c_{i}+v_{i}+v_{i t}
$$


where lac is a dummy variable that takes the value of 1 if the country in question is in the Latin American region and 0 otherwise. Thus the impact of remittances on growth for Latin America would be given by $\beta_{1}+\beta_{2}$.

As for the impact of remittances on inequality, we follow a similar strategy and estimate the following specification:

$$
g_{i t}-g_{i t-1}=\lambda g_{i t-1}+\chi^{\prime} x_{i t}+\alpha_{1} r_{i t-1}+\alpha_{2} r_{i t-1} \times l a c_{i}+\mu_{i}+\varepsilon_{i t}
$$

where $g$ is the (logged) Gini coefficient, and $\mu_{i}$ and $\varepsilon_{i t}$ are a country-specific effect, and an i.i.d. error term. Analogous to equation (5), the impact of remittances on the changes in inequality for Latin America would be given by $\alpha_{1}+\alpha_{2}$.

\section{(c) Econometric issues}

In equations (5) and (6) above, the variable for remittances is pre-determined, which in principle should help alleviate concerns with simultaneity. This in turn should offer some reassurance that empirical estimates of $\beta$ and $\alpha$ capture the effect of remittances on growth and inequality rather than the impact of growth or inequality on migration and hence on remittances.

However, the estimation of equations (5) and (6) still has to overcome two main challenges, namely the presence of (unobserved) country-specific effects potentially correlated with the explanatory variables, and the possible simultaneity of some of the control variables with growth. To address the first of these issues Arellano and Bond (1991) propose differencing the equations to eliminate the country specific effect so that, after rearranging, (5), say, can be rewritten as:

$$
\begin{aligned}
& \left(y_{i t}-y_{i t-1}\right)=(1+\delta)\left(y_{i t-1}-y_{i t-2}\right)+\omega^{\prime}\left(x_{i t}-x_{i t-1}\right)+\beta_{1}\left(r_{i t-1}-r_{i t-2}\right) \\
& +\beta_{2}\left(r_{i t-1} l a c_{i}-r_{i t-2} l a c_{i}\right)+\left(v_{i t}-v_{i t-1}\right)
\end{aligned}
$$

which relates changes in the growth rate to changes in remittances and the control variables. If $\delta$ $=0$ and the $x$ variables are exogenous, OLS on (7) will yield consistent estimates. But if $\delta$ is not equal to zero, and/or some or all of the $x$ are determined simultaneously with $y$, the OLS estimates will be inconsistent, and an instrumental variable procedure is needed to obtain consistent estimates of the parameters.

Absent exogenous variables that can provide external instruments, a GMM estimator based only on internal instruments can be constructed along the lines of Arellano and Bover (1995) and Blundell and Bond (1998), who propose a system estimator combining the regressions in differences and levels. To compute the system estimator, predetermined and endogenous variables in first differences are instrumented with suitable lags of their own levels, while variables in levels are instrumented with suitable lags of their own first differences. ${ }^{10}$

\footnotetext{
${ }^{10}$ A well-known shortcoming of panel GMM estimators in small samples is their tendency to result in over-fitting and downward-biased standard errors - a consequence of the large number of instruments available for estimation
} 
In this context, however, there is the possibility of finding instruments that can be considered exogenous and yet be correlated with remittances. In this regard we employ both internal instruments based on lagged levels and first differences of the remittances variable, and two types of external instruments based on the economic conditions of the countries in which most remittances to developing countries originate. The first variable is based on the per capita GDP of each of the top ten migrant receiving countries of the world, weighted by the inverse of the distance to these ten countries from each remittance receiving country in our sample. We will refer to this series as the Distance variable. The second external instrumental variable is based on the real GDP per capita of the five OECD countries that are the top receivers of migrants for each remittance receiving country, weighted by the share of migration from the corresponding country to each of those five OECD destinations. We refer to this series as the Migration series. In each case, we consider as potential instruments the (logged) level of the variables at the beginning of the period and the growth rates over the period under consideration. ${ }^{11}$

The consistency of the GMM estimator above depends on the validity of the assumption that the error terms do not exhibit serial correlation as well as on the validity of the instruments. We present two specification tests to address these issues. The first is the Sargan test of overidentifying restrictions. The second test examines whether the error term $v_{i t}$ in (7) is not serially correlated, which in turn would imply that the difference error in (9) does not present second-order serial correlation (SOSC).

\section{(d) Control variables}

We turn to the specification of the set of control variables included in $x$. There is a wide array of potential explanatory variables that can be used in this context. ${ }^{12}$ In this paper, rather than adding to the already huge variety of growth models, we opt for considering a set that has already been used in a number of empirical growth studies. This is the one used by Perotti (1996), Forbes (2000), Banerjee and Duflo (2003), and Knowles (2005), and it includes the average years of secondary education of the male population, the average years of secondary education of the female population, and a measure of market distortions: the price of investment

(see, e.g., Ziliak 1997). To reduce this bias, in the estimations below we limit the number of over identifying restrictions by building only one instrument from each variable and lag distance, rather than building one separate instrument from each variable, and lag distance in each time period.

11 The basic intuition behind these instruments is that migrants tend to send more money to their home countries when they face improved economic conditions in the countries where they are established. Thus, higher growth in a given migrant-receiving country is likely to lead to increased remittances flows to countries that have a large share of their stock of migrants located in that country. Moreover, since the importance of each developed country as a destination for migrants of a given developing country is inversely correlated with the distance between those countries, the effect of growth in the former on the flows of remittances to the latter is likely to decrease with the distance between them. In other words, remittances will likely be positively related to growth in migrant destination countries, to the existing stock of migrants in those countries, and to the inverse of the distance between them. On the other hand, the proposed instruments are not likely to affect growth or inequality in migrant-sending countries, beyond their effect through changes in remittances flows..

${ }^{12}$ As noted by Durlauf and Quah (1999), by 1998 the number of individual regressors that had been considered as potential explanatory variables in growth regressions exceeded the number of countries in the standard growth dataset. 
goods relative to the one in the US. All these variables are measured in levels at the beginning of the period.

This choice of regressors is motivated by three main considerations. First, we need a parsimonious model as the number of available observations dramatically falls once we estimate the equations for inequality, a variable for which data availability is quite limited. Second, this choice ensures comparability with existing work in the growth literature Third, the selected controls are relevant as explanatory variables both for our growth and inequality regressions. In this respect, even though Perotti (1996) justifies the selected regressors in a growth context, their relevance can also be defended as determinants of inequality. Indeed, education is usually seen as one of the main determinants of inequality and discriminating between female and male educational levels can also capture gender-related inequalities. Finally, the price of capital can capture incentives to substitute capital for labor. ${ }^{13}$

Clearly, omitted variable bias could be problematic if there is strong correlation between the dependent variable in question, the remittances variable and a third omitted variable. Moreover, given the large potential number of variables that could be included in a growth regression it is almost impossible to infer how omitted variables could affect the estimates of remittances, growth and inequality. Here we have to admit that there is little that we can do other than, as stressed above, relying on a control set that has been extensively used in the literature, and on the fixed effects strategy to somewhat correct the problem, particularly when the omitted variables are time invariant or have low variability.

\section{CROSS-COUNTRY DATA AND RESULTS}

\section{(a) Cross-Country Data}

We use data for 59 industrial and developing countries spanning the years 1970-2000. All the regressions are performed using non-overlapping five year periods. The education variables come from the Barro and Lee (2001) database, income and the proxy for market distortions are from the PWT6.1 database, and the Gini indices are from Dollar and Kraay (2002). Remittances data are as in Aggarwal, Demirguc-Kunt, and Martinez Peria (2005) and the data come from the World Economic Outlook (2005). With some exceptions, these data are constructed as the sum of three items in the Balance of Payment Statistics Yearbook (IMF): workers' remittances (current transfers made by migrants who are employed and resident in another economy); compensation of employees (wages, salaries and other benefits earned by nonresident workers for work performed for resident of other countries); and migrant transfers (financial items that arise from the migration or change of residence of individuals from one economy to another). Once we bring all the variables together we end up with a sample of 221 observations in the growth regressions and a sample of 85 observations in the specifications for the Gini coefficient. To a large extent the difference in the size of these samples is driven by the different coverage of the income and inequality variables. ${ }^{14}$

\footnotetext{
${ }^{13}$ Clearly, as in the case of the growth equation, there are many other variables that one could potentially consider as determinants of inequality, including the age profile of the population, the country's fertility rate, etc.

${ }^{14}$ In fact, whereas the PWT6.1 allows for the construction of more than 700 5-year observations for the growth variable between 1970 and 2000, the Dollar and Kraay (2002) database only allows for 274 observations for the
} 


\section{(b) Growth and Inequality Results}

The results of estimating the growth equation (7) are reported in table 1. Each column reports the results that are obtained when the GMM estimator described above is implemented using a different instrument set. The estimation in column (1) is based on internal instruments only. Columns (2) to (7) use in addition to the internal instruments for the control variables (female and male education and the cost of investment) one exogenous variable (either Distance of Migration) that can enter in the instrument set in levels, growth rates, or both. In all cases the validity of the chosen instrumental variables is confirmed by the Sargan and second order serial correlation tests, which do not reveal any serious misspecification problem. ${ }^{15}$

\section{TABLE 1 HERE}

Inspection of this table indicates that remittances tend to have a positive and statistically significant effect on growth regardless of the instrument set used. The estimated slopes range between .005 and .013 , implying that doubling the share of remittances in GDP would on average increase growth by between .5 and 1.3 percentage points. The finding that higher remittances would lead to higher growth holds both for the typical country of the world and for the average Latin American and Caribbean country. Indeed, the interaction term between remittances and the Latin America dummy is not statistically different from zero, implying that the impact of remittances on growth is the same in Latin America and the rest of the world..

Regarding the coefficients of the other control variables, as expected the proxy for the cost of capital carries a negative coefficient although it is not always significantly different from zero. In turn, the education variables carry coefficients of opposite signs, in line with the findings of other studies such as Perotti (1996), Forbes (2000) and Knowles (2005). ${ }^{16}$ The only somewhat disappointing result is the positive sign that lagged income carries which would be at odds with (conditional) convergence arguments. ${ }^{17}$

In sum, the results that emerge from table 1 would suggest that remittances are good for growth. We next address whether remittances are also good for income inequality. Table 2 reports the results of estimating model (8) and we start by noting that, as in the growth equation case, the specification tests do not indicate any particular misspecification problem. However, unlike in the previous case, the results are now more mixed. For example, when we use the Distance-level, Distance-growth and Migration-growth instruments we do find that, at the global level, remittances tend to be associated with higher levels of inequality but do not find a significant impact for Latin America. With the rest of instruments we still find a positive impact on the Gini coefficient at the global level, but now the Latin American specific impact is

\footnotetext{
changes in the gini variable for that same period. The problem is subsequently compounded when we cross these two variables with the rest of the database.

${ }^{15}$ The results of the estimation remain virtually unchanged when we include among the regressors a time effect to account for the effect of common events to all countries in the sample.

${ }^{16}$ See e.g., Table 4 in Perotti (1996), Table 4 in Forbes (2000) and Tables 1 and 3 in Knowles (2005). Perotti (1996) explains this noting that "lower initial female attainment, indicates more backwardness and therefore faster subsequent growth as the economy converges toward its steady state" (Perotti, 1996, p.159)..

${ }^{17}$ Note, however, that using a similar specification Knowles (2005) has also failed to find evidence of cross-country conditional convergence.
} 
negative and significant. In other words, while for the average country of the world increase in remittances would lead to higher income inequality, the effect for the average Latin American country is either negative or non-significant depending on the specific choice of instruments. This result can be interpreted in light of the fact that remittances are more likely to have an equalizing effect on income when they are directed to a larger extent to households in the lower quintiles of the income distribution. In particular, the above results are consistent with migration costs in Latin America being lower with respect to per capita income than in other regions of the developing world, possibly because of smaller distances to migrant destinations or because of long standing migration networks - e.g. as in the case of the Mexico-U.S. corridor.

\section{TABLE 2 HERE}

As for the magnitudes of the effects of remittances on the Gini coefficient, we find that they are very similar to those found for growth, at least for the average country in the sample, in which doubling the share of remittances would lead to increases of between 0.5 and 1.1 percent in the Gini coefficient. Note, however, that in the case of the average Latin American country, remittances have a positive effect on growth but a negative or non-significant effect on inequality. In the case of this region, considering only the specifications that yield significant remittances effects, the later are such that an hypothetical one percentage point increase in the remittances to GDP ratio for a country where that share is 4.9 percent - as in the average Latin American country - would lead to a reduction in the Gini of between 0.06 and 0.12 percent.

\section{(c) Poverty Results}

The previous discussion would indicate that remittances would lead to lower poverty in Latin America. This is illustrated in table 3 which reports the poverty elasticity with respect to the remittances to GDP ratio obtained for the average Latin American country, for each of the specifications used. In building this table we have made use of the estimates for the impact of remittances on growth and inequality reviewed above and of estimates for $\gamma$ and $\phi$ in equation (5) derived under log-normality and taken from Lopez and Serven (2006). ${ }^{18}$

\section{TABLE 3 HERE}

Evidence in Table 3 indicates that there is substantial heterogeneity of results depending upon the country's initial conditions, as given by the ratio of per capita income to the poverty line, and the Gini coefficient. This reflects the different values that the growth and inequality elasticities of poverty take as those initial conditions change (see Lopez and Serven, 2006 for a discussion). In fact, depending on the model being used and on the initial conditions, a 10 percent increase in the share remittances in GDP would lead to a reduction in poverty that varies from 0.03 to 1.5 percent - respectively for countries with high and low levels of both inequality and development. In the Latin American context, however, this range can be substantially narrowed as most countries in the region have Gini coefficients of around 0.5. ${ }^{19}$ Thus, considering that in the average Latin American country remittances are 4.9 percent to GDP, a

\footnotetext{
${ }^{18}$ Note that these results rely on the log normality assumption of income and that other assumptions would produce other results.

${ }^{19}$ See for example Figure 4.7 in Perry et al. (2006).
} 
one percentage point increase in the remittances to GDP ratio is estimated to lead to reductions in poverty that vary between 0.08 percent for poorer countries to 1.12 percent for richer countries, with an average estimated reduction of 0.37 percent. $^{20}$

\section{MICRO-ECONOMETRIC EMPIRICAL STRATEGY}

\section{(a) Inequality Decompositions}

As argued in the seminal paper by Stark, Taylor and Yitzhaki (1986), the impact of migration and international remittances on income inequality depends on the magnitude of remittances in relation to income from other sources and upon the position of remittancereceiving households in the distribution of income. In their perspective, the uncertainty, net expected benefits and the distributional impact of migration "investments" depend, at any point in time, on past migration flows.

In particular, when migration is incipient, its costs and related uncertainty are likely to be high, so that migrants can be expected to come from among the better off. As a result, at this point remittances would tend to have an un-equalizing effect. Over time, however, the uncertainty and costs involving migration are likely to diminish with the spread of information and contacts across a wider range of households, which may lead to increases in migration among the worse off, with potentially favorable effects on income inequality.

To illustrate their hypothesis, Stark, Taylor and Yitzhaki (1986) proposed a decomposition of income inequality that allows estimating the effects of discrete and marginal changes in remittances on the distribution of household income. We use this as a first approach to uncovering the link between remittances and inequality on the basis of household survey data from 10 Latin American countries. ${ }^{21}$ It must be noted, however, that this approach entails the assumption that remittances operate as exogenous transfers by migrants, so that the implicit counterfactual scenario is that of changes in remittances without changes in migration. In other words, initially we do not consider the fact that migration also entails losses of income associated with the migrants' absence from their communities.

Following Stark, Taylor and Yitzhaki (1986), let $y_{k}$ represent the different $k$ components of household income (i.e., non-remittances and remittances income). The Gini coefficient for any particular income source $\mathrm{k}$ can be written as:

$$
G_{k}=2 \frac{\operatorname{COV}\left[y_{k}, F\left(y_{k}\right)\right]}{\mu_{k}}
$$

\footnotetext{
${ }^{20}$ This is the estimated poverty effect of one percentage point increase in the remittances to GDP ratio in a country where that ratio is 4.9 percent and the Gini Coefficient is 0.5 , using the average poverty elasticity from all alternative choices of instrumental variables reported in table 3.

${ }^{21}$ This type of decomposition has been used, among others, by Rodriguez (1998) and by Barham and Boucher (1998).
} 
where $\mathrm{F}\left(y_{k}\right)$ represents the cumulative distribution of income source $\mathrm{k}$, and $\mu_{k}$ denotes country mean income. Defining $G_{T}$ as the Gini coefficient of total income, the properties of covariance allow the following decomposition:

$$
G_{T}=\frac{2 \sum_{k=1}^{K} \operatorname{COV}\left[y_{k}, F\left(y_{T}\right)\right]}{\mu_{T}}=\sum_{k=1}^{K} R_{k} G_{k} S_{k}
$$

where $S_{k}$ is the country's share of income source k on total income, and $R_{k}$ is the Gini correlation of component $\mathrm{k}$ with total income, i.e.:

$$
R_{k}=\frac{\operatorname{COV}\left[y_{k}, F\left(y_{T}\right)\right]}{\operatorname{COV}\left[y_{k}, F\left(y_{k}\right)\right]}
$$

Stark, Taylor and Yitzhaki (1986) also show that this formulation can be used to calculate the effect of a small percentage change in one source of income - e.g. remittances - on the Gini coefficient of total income. This effect is given by:

$$
\frac{\partial G_{T} / \partial k}{G_{T}}=\frac{S_{k} G_{k} R_{k}}{G_{T}}-S_{k}
$$

which shows that an infinitesimal change in income $\mathrm{k}$ has equalizing (un-equalizing) effects if the share of the Gini explained by that income source is smaller than its share in total income.

\section{(b) No-Migration Counterfactual}

The results of the above inequality decompositions can arguably be misleading if one assumes that remittances are not exogenous transfers but rather they substitute for the home earnings that migrants would have had if they had not decided to leave their countries to work abroad. In particular, in this approach the non-remittances income reported by households with migrants is not a good representation of the situation of the family prior to migration. In effect, if the migrant had positive earnings before leaving the household, it is likely that household's total non-remittances income is lower after migration. Thus, estimating the effect of migration and remittances on inequality would require taking into consideration the counterfactual per capita income that the household would have had if the migrant had stayed at home.

To address this issue, we impute per capita household income for migrant families in the counterfactual scenario of no remittances and no migration. ${ }^{22}$ We do this by predicting per capita income levels for households with remittances on the basis of a reduced-form specification for

\footnotetext{
22 Previous papers that have attempted to make corrections with a similar approach - although with different estimation and simulation methodologies - are Adams (1989, 2004, 2006), Rodriguez (1998), and Barham and Boucher (1998).
} 
the determinants of income among households without remittances. The estimated model is the following:

$$
\log Y_{i}=\alpha+\beta X_{i}+\gamma H_{i}+\mu_{i}
$$

where $Y i$ represents per capita non-remittances income, $X_{i}$ is a vector of household characteristics (demographic and location covariates), $H_{i}$ is a set of characteristics of the household head, and $\mu_{i}$ is unobserved heterogeneity in income generation. The procedure consists on estimating equation (12) for the sub sample of households that do not receive remittances. The estimated coefficients allow predicting the counterfactual non-migration income for remittances-recipient households. In order to avoid the reduction in income variability for migrant families due to the used of predicted values, we follow Barham and Boucher (1998) in adding to the predicted values of income a simulated error component.

Several issues need to be discussed. First, in the absence of information on migrant characteristics - which is the case in eight out of our ten countries - it is necessary to make some basic assumptions about the number and the demographics of migrants. In this respect, we follow Rodriguez (1998) in assuming that on average remittances are sent by an adult male family member, who has the average years of education of other adults in the household. The assumption that the remittance sender is a male relative is justified by the fact that the surveys for Haiti and Nicaragua, which contain information on migrants' demographics, indicate that respectively 74 and 61 percent of households that receive remittances have at least one adult male migrant abroad that is a close relative or part of the extended family, and 80 and 99 of the remaining recipient households have an adult female migrant that is a close family member (the Haitian survey only reports close migrant family members). On the other hand, the assumption that remittances are sent by just one migrant can be considered to be a conservative one, as at least in Haiti and Nicaragua recipient households report, on average, respectively 2.2 and 1.8 adult migrants living abroad. Our assumption regarding the schooling of migrants also appears to be on the conservative side, as the Nicaraguan survey suggests that adult migrants have slightly higher average years of education (7.7) than non-migrant adult household members (6.7 years) which may also lead to a small under-estimation of counterfactual non-remittances income. ${ }^{23}$

Second, OLS estimates of equation (12) would be inconsistent if $\mu_{\mathrm{i}}$ is not independently identically distributed (i.i.d.). In other words, if migrants are not randomly selected from the pool of households, estimates of equation (12) based on the sample of households without migrants could suffer from selection bias. To control for possibility, we add a variable that represents the "propensity to migrate", in the context of the two-step estimation framework proposed by Heckman (1979). ${ }^{24}$ In particular, we adopt the following model specification:

\footnotetext{
${ }^{23}$ The Haitian survey does not allow for such a comparison of schooling levels between migrants and their relatives. Moreover, potentially compensating the above mentioned effects of our assumptions, it must be noted that for the minority of recipient households who report not having adult migrants that are close relatives -8 percent in Nicaragua - we are probably over-estimating their counterfactual income in the absence of migration and remittances, as the remittance sender probably did not live in the household prior to migrating.

${ }^{24}$ A similar approach is followed in Barham and Boucher (1998) and Adams (2006).
} 


$$
\begin{aligned}
& M_{i}^{*}=\alpha_{1}+\beta_{1} X_{i}+\gamma_{1} H_{i}+\omega Z_{i}+\mu_{i} \\
& \text { (no-remittances selection rule) } \\
& \log Y_{i}=\alpha_{2}+\beta_{2} X_{i}+\gamma_{2} H_{i}+\theta \lambda_{i}+\varepsilon_{i} \\
& \text { (earnings equation for non-recipient families) }
\end{aligned}
$$

We only observe the sign of the variable $M_{i}^{*}$, which represents the selection rule for not receiving remittances i.e. we observe only whether the household receives remittances or not, which in turns is equivalent to a negative or positive value for $M_{i}{ }^{*}$. Identification of this model requires an exclusion restriction: a set of variables $Z_{i}$ that are related to the migration and remittances choice but which do not directly affect earnings for households without -migrants. The term $\lambda_{i}$ is the selection inverse Mill's ratio, defined as:

$$
\lambda_{i}=\frac{\phi\left(\alpha_{1}+\beta_{1} X_{i}+\gamma_{1} H_{i}+\omega Z_{i}\right)}{1-\Phi\left(\alpha_{1}+\beta_{1} X_{i}+\gamma_{1} H_{i}+\omega Z_{i}\right)}
$$

with

$$
\theta \lambda_{i}=E\left(v_{i} / \mu_{i}>-\beta_{1} X_{i}-\gamma_{1} H_{i}-\omega Z_{i}\right)
$$

where $\mu_{i}$ is the error component in the earning equations and $\theta=\operatorname{cov}\left(v_{i}, \mu_{i}\right) / \sqrt{\operatorname{var}\left(\mu_{i}\right)}$.

Controlling for $\lambda_{i}$ allows the remaining unexplained component $\varepsilon_{i}$ to have the usual desirable i.i.d. properties. If $\lambda_{i}$ is a significant predictor of earnings, it suggests that the selection into the non-migration status is indeed correlated with factors that affect the household earnings - and that OLS estimates of equation (12) would be inconsistent.

The exclusion restrictions that we employ for the no-remittances selection equation are an index of household assets, the percentage of households that receive remittances in the respective county of residence (a proxy for the presence of migrant networks), and their interaction. When county level indicators cannot be calculated (Guatemala and Haiti), the variable that represents the percentage of households with remittances is measured at the department/province level. In this case, only the interaction of that variable with the household assets index is included. Finally, when information on household assets is missing (Bolivia, Ecuador and Honduras), the network variable is interacted with the number of adult males, which ensures variability at the household level. ${ }^{25}$

25 Our motivation for using the interaction between migrant networks with household assets or the number of adult males (when information on household assets is missing) is to allow migrant networks to have a different effect on households with different predispositions to migrate in the first place. In this respect, households with a larger number of adult males have a higher likelihood of sending migrants abroad, while the same is true for those with more assets, whom are more likely to be able to afford the costs of migration. 
With the assumption stated before concerning migrant characteristics, these coefficients are used in order to impute the counterfactual non-remittances per capita household income for recipient families. With this variable one can proceed to calculate the levels of poverty and inequality that would have prevailed had migration and remittances not taken place. It must be noted, however, that as mentioned by Rodriguez (1998) the variance of the counterfactual income predicted on the basis of observable household characteristics is artificially small, because it ignores unobserved determinants of income.

A potential solution proposed by Barham and Boucher (1998) is to add to the predicted household income a random error component drawn from a distribution with the same properties (mean, variance) of the actual estimated errors. We pursue this approach and obtain 1,000 different estimates of the imputed counterfactual non-remittances income for families with migrants, and the same number of estimates for the poverty and inequality levels that would have prevailed in the above counterfactual scenario. This allows us to report not only point estimates for those variables but also $95 \%$ confident intervals, based on the 25 th and 975 th estimates of the variables - after sorting them ascending order.

\section{HOUSEHOLD SURVEY DATA AND RESULTS}

\section{(a) Data}

We use household surveys data for 10 Latin American and Caribbean countries: Bolivia, Ecuador, El Salvador, Guatemala, Haiti, Honduras, Mexico, Nicaragua, Paraguay and Peru. These countries were selected as they have recent household survey data with questions on remittance receipts. Our interest in these countries is also driven by the fact that, as it emerges from Figure 1, most rank among the top receivers in the region in terms of remittances to GDP ratio in 2004 (Haiti, Honduras, El Salvador, Guatemala, Nicaragua, and Ecuador). Moreover, as shown in the lower panel of figure 1, Mexico is the top LAC receiver of remittances and one of the world's top receivers in absolute terms (18.1 billion USD in 2004). Finally, Paraguay, Bolivia and Peru are also interesting cases as they generate considerable flows of South-South migration, which we are interested in comparing with the more traditional South-North pattern.

All the household surveys that we employ are nationally representative, they were performed between 2000 and 2004, and contain information on the amount of foreign remittances. It must be noted, however, that none of these surveys has a panel structure (i.e. none follows the same household over time) and only two contains detailed information on migrants (Haiti and Nicaragua). Household surveys are not uniform across countries. The issue of comparability is of great concern, although we have made all possible efforts by using similar definition of variables in each survey. Table 4 provides details on the household surveys employed.. In the definition of household income, in general all income sources are considered, with the exception of imputed own-housing rent. ${ }^{26}$

\section{TABLE 4 HERE}

\footnotetext{
${ }^{26}$ The concepts employed for defining non-remittances income and the questions used to collect information on remittances are available upon request.
} 
A remaining methodological remark is that, although it is well known that household consumption is a better proxy for well-being than income, we decided to use household income when computing poverty and inequality measures due to the following reasons: a) the interest in the evaluation of differential impacts by income source (i.e., non-remittances vs. remittances income); b) few countries in the region have survey data with questions on household consumption and expenditures, while all of them include information on income.

\section{(b) Inequality Decompositions}

Table 5 presents a decomposition of the Gini coefficient of total income calculated on the basis of equation (11). For each country the first two rows present statistics associated respectively with non-remittances income - labor income, capital gains and transfers within the country - and remittances. Those statistics include the corresponding share in total income, the Gini coefficient, the Gini correlation with total income - see equation (10) - and the absolute and relative contribution of each income source to the Gini of total income. The last column of the table presents the effects on total income inequality of marginal changes in each income source, calculated using equation (11).

\section{TABLE 5 HERE}

The first way of analyzing these results to determine whether remittances increase or decrease income inequality is by comparing the Gini coefficient in the absence of remittances, to the Gini coefficient of total income. With the exception of Nicaragua and Peru, all countries exhibit higher Gini coefficients for non-remittances income, suggesting that if remittances were exogenously eliminated - without any compensating change in other sources of income, for instance through the local earnings of would-be migrants - inequality would increase. Quantitatively, however, the estimated potential increases in the Gini coefficient are small, averaging 1.8 percent in the countries where inequality would decrease, and 0.2 percent in the two countries in which the Gini would decrease. The large potential change is found for El Salvador, where we find found that the Gini would increase from 0.486 to 0.514 in the absence of remittances.

One of the factors that explain the small inequality reducing effect of remittances is the fact that their own distribution is generally very unequal. Thus, the Gini coefficient for remittances is found to be above 0.9 in all ten countries (as most households do not report receiving remittances). In some of them, however, the high inequality in the distribution of remittances is partially compensated by a low Gini correlation between remittances and total income, which increases the equalizing effect that those flows have on total income. This is the case of Mexico, where the Gini correlation of remittances with total income is 0.289 , El Salvador (0.303), Paraguay (0.437) and Guatemala (0.541). Not surprisingly, we find that in these four countries a marginal increase in remittances has an equalizing albeit small effect on income inequality. In particular, it is estimated that a 10 percent increase in remittances would lead to an average reduction of 0.1 percent in the Gini of total income in those four countries.

In contrast, in the other six countries, where remittances are more highly correlated with total income, the households that receive them are located mainly in the upper quintiles of the 
income distribution. This is more clearly seen in Haiti, Nicaragua and Peru, and leads to very small reductions or even positive effects on income inequality in the hypothesis of the elimination of remittances. Moreover, we find that in those countries a marginal increase in remittances is associated with an increase in total income inequality: the Gini increases by 0.2 percent on average for each 10 percent increase in remittances income.

\section{(c) Poverty and Inequality in No-Migration Counterfactual}

The estimates obtained for the two-step model described in equations (13) and (14) are available upon request. Nevertheless, we can anticipate that unlike in Barham and Boucher (1998) and Adams (2006), who found insignificant selection coefficients $\left(\lambda_{i}\right)$, in almost all cases (except Ecuador) the variable associated with the "propensity to not receive remittances" is positive and significant at 1 percent level, suggesting that recipient of remittances are not randomly selected from the complete pool of households. Moreover, it appears that households with a higher propensity to not migrate are more likely to have higher per capita income levels, which is consistent with the standard migration argument that potential migrants compare the returns at home and in their potential destination when deciding whether to work abroad.

The rest of the coefficients have the expected signs. In the selection equation, larger families (in particular, with a higher number of adult males) are more likely to receive remittances (or migrate). On the other hand, a higher number of children or adult females are negatively related to the likelihood of migration and remittances receipts. ${ }^{27}$ Higher educational levels are negatively related to remittances, except in Haiti and Honduras (where education has the opposite sign). The presence of migrant networks, proxied by the percentage of households with remittances in the area of residence, and a household assets index are also positive correlated with the likelihood of being a recipient. ${ }^{28}$ In the earnings equation, as expected, education and demographic characteristics are strong significant predictors of income in nonrecipient households, explaining between 33 and 55\% of income variability depending on the case.

Table 6 shows the position of households that report receiving remittances in the distribution of income, defined in three alternative ways: non-remittances income, imputed nonremittances income (in the no-migration counterfactual), and total observed income. ${ }^{29}$ In general, when comparing the distribution of recipient families according to non-remittances income with the distribution along either imputed non-remittances income or total income, we observe that

\footnotetext{
27 The result that for a given number of adult males in the household, an increase in the number of children and/or adult females is associated with a lower probability of receiving remittances is consistent with the fact that children and females are less likely to be active in the labor market. Thus, households with many females and dependent children may be less willing to send migrants to work and remit money from abroad, both because they may less capable of paying the costs of migration, and because they may be less able to complement remittances with other local sources of labor income.

28 The household assets index was constructed using First Principal Components technique. Asset holdings considered were (whenever data is available): number of rooms per adult equivalent; cement walls; cement/brick floors; W.C. inside property; access to water, electricity, and telephone services; and ownership of automobile, refrigerator, TV, VCR, washing machine, and sewing machine.

${ }^{29}$ The values reported for the counterfactual exercise are the mean results of the 1,000 imputation generation process using random draws in order to approximate unobserved heterogeneity.
} 
recipients experience substantial upward shifts along the income distribution. For instance, 61 percent of the Mexican households that receive remittances are in the first quintile of the distribution of observed non-remittances income, but that fraction falls to 25 and 26 percent for the other two income definitions. This confirms that as a measure of the counterfactual nonmigration income of recipients, the observed non-remittances income suffers from a substantial downward bias, presumably because recipient families loose significant income earners in the migration process. Similar results are found in all countries.

\section{TABLE 6 HERE}

Table 6 also serves as a characterization of the socioeconomic status of recipient families. Thus, it is clear that in some countries migrants and recipient families tend to come from definite socioeconomic segments of society. For instance, even after correcting for the potential downward bias in reported non-remittances income, both tables with actual and imputed values suggest that a higher proportion of migrants tend to come from the bottom of the income distribution in Mexico and Paraguay. ${ }^{30}$ In contrast, for Haiti, Peru and Nicaragua, we find evidence that goes in the opposite direction: migrants seem to be "positively selected", in the sense of coming from the upper quintiles of the income distribution. The evidence concerning negative selection in Mexico and Paraguay, and positive selection in Haiti, Peru and Nicaragua seems to be corroborated by the distribution of recipient families according to the average years of education of actual adult members and household assets index (Table 7). For the other countries the evidence is not conclusive, with migrants showing a more uniform distribution along the various measures of income/wealth/education.

\section{TABLE 7 HERE}

Table 8 shows estimates of the Gini coefficient using counterfactual imputed nonremittances income for recipient families. The general trend is that remittances have an even less equalizing effect in comparison to what had been obtained when using reported non-remittances income. The equalizing effect of remittances is much lower in six out of ten countries. For two of them, Mexico and Paraguay, remittances now even seem to increase inequality - although the evidence is not conclusive in Paraguay, according to the $95 \%$ confidence interval on the imputed Gini before remittances.

\section{TABLE 8 HERE}

On the other hand, in Haiti, Guatemala, Nicaragua and Peru, where migrants come from the upper segments of the income and educational distribution, the evidence is quite the opposite. For these countries, remittances now reduce inequality much more than before. Thus, when calculated using imputed non-remittances income, the Gini coefficient "before remittances" is higher than the Gini for observed total income. The most notable difference is registered in Haiti: the fall in inequality with respect to the no-remittances scenario was of 0.09 percent, but the reduction in the Gini starting from the no-migration scenario is now found to be of 7.67 percent. In Nicaragua and Peru, the effect of remittances on inequality actually switches from positive to negative when using imputed as opposed to reported non-remittances income.

\footnotetext{
${ }^{30}$ For the Mexican case, these results agree with Ibarraran and Lubotsky (2005).
} 
The estimated elasticities of inequality with respect with the share of remittances in household income in the no-migration counterfactual are also reported in table 8 . They vary from -0.91 for Guatemala and -0.74 in Nicaragua, to 0.16 and 0.37 for Paraguay and Mexico, respectively. ${ }^{31}$ Overall, when one moves from the no-remittances to the no-migration counterfactuals the average inequality effect that results from a one percentage point increase in the remittances to GDP ratio falls (in absolute value) from 0.37 to 0.25 . Even the later inequality effect, however, is twice as large as the highest estimates reported above for Latin America, on the basis of cross-country regressions.

The results for Mexico, Paraguay and the other four countries for which remittances' impact is minor or even favoring inequality are consistent with the findings of previous studies that have made attempts to calculate counterfactual pre-remittances income in remittancesreceiving families. Rodriguez (1998) found that the increase in inequality after remittances in the Philippines rises from 1.27 percent to 7.90 percent when using imputed income instead of reported values. Similarly Barham and Boucher (1998), for the case of Bluefields (Nicaragua), reported that the Gini for household income falls from 0.47 to 0.43 when using reported figures, but inequality actually rises from 0.38 to 0.43 after correcting the pre-remittances distribution using imputed income for migrant families.

Table 9 reports simulations of the effects of remittances and migration on poverty levels. The results show that attempts to estimate the poverty-reducing effect of remittances based only on the analysis of observed non-remittances income grossly over-estimate those effects. We employ two commonly headcount poverty indicators, based on poverty lines of US\$1 and US\$2 per person per day, measured at PPP values, corresponding respectively to "extreme" and "moderate" poverty. ${ }^{32}$ The first columns on both the left and the right hand side panels show results without correcting for the potential home earnings of migrants - i.e. based on the counterfactual scenario of no-remittances but no change in migration. As expected, remittances lead to large reductions in poverty levels, especially in those countries where migrants tend to come from the lower quintiles of the income distribution - notably Mexico and El Salvador, where extreme poverty is estimated to fall by more than 35 percent and moderate poverty by respectively 15 and 21 percent. However, when observed levels of poverty are compared to the less simplistic scenario of no-migration - that is when imputations are made for the income of migrants - the levels of poverty reduction are much lower. The most striking case is again that of Mexico, where poverty is now found to increase as a result of migration. ${ }^{33}$

\footnotetext{
${ }^{31}$ These elasticities are calculated as the ratio between the percent change in inequality and the share of remittances in income in the corresponding country: e.g. for each 1 percent reduction in the remittances to income ratio of Guatemala, inequality is estimated to increase by 0.94 percent.

${ }^{32}$ The US\$ 1 and US\$ 2 a day are values measured in 1989 international prices and adjusted to local currency using purchasing power parities (PPP) to take into account local prices. Although these lines have been criticized, their simplicity and lack of reasonable alternatives have made them the standard for international poverty comparisons. For instance, they are periodically presented in the World Development Indicators (World Bank).

${ }^{33}$ Large poverty reducing effects when using observed non-remittances income as a counterfactual are to some extent driven by the fact that many recipient households report very little or no non-remittances income. As previously discussed, to the extent that their income prior to migration was higher, for instance because more household members were active in the labor market (including the migrant), that approach leads to over-estimating the poverty reducing effects of remittances. We attempt to correct this problem by using as a counterfactual the households' "potential income", assuming that prior to migration they behaved like similar non-recipient households with the same probability of migration. However, it is worth noting that we may fail to capture unobserved
} 


\section{TABLE 9 HERE}

On average, when moving from the no-remittances to the non-migration counterfactual scenarios, the reduction in extreme poverty falls from 14 to 3 percent and that in moderate poverty from 8 to 3 percent. In terms of the average estimated impact of remittances on poverty, in the non-migration counterfactual, moderate and extreme poverty are estimated to fall by respectively .57 and .50 percent for every percentage point increase in the remittances to nonremittances household income ratio. For comparison purposes with the cross country exercise, we have also computed the change in poverty in the counterfactual absence of migration and remittances, assuming that the actual ratio of the later to GDP is as measured by Balance of Payments data. In this case, the average impact on extreme and moderate poverty of a 1 percentage point increase in the remittances to GDP ratio is estimated at respectively .37 and 0.40 percent (i.e. fully in line with the cross country results).

Regarding poverty gap and squared poverty gap, Table 10 summarizes the results which suggest that in general remittances tend to reduce the depth of poverty. Using reported income, just in one case (Peru) remittances are associated to a small increase in poverty depth. Again, Mexico and El Salvador are the countries in which remittances severely reduce poverty depth. On average, extreme and moderate poverty depth are reduced in 4 and 2 percentage points respectively after a 1 percentage point increase in the remittances to income ratio. Using imputed non-remittances income, poverty depth results re more varied, still decreasing after remittances in the majority of cases, but also showing many cases with inconclusive remittances' impacts (switching sign in the confidence interval reported) and with a positive association between remittances and poverty depth (increasing extreme poverty depth in El Salvador, Honduras and Peru, and moderate poverty depth in Honduras).

\section{TABLE 10 HERE}

\section{CONCLUDING REMARKS}

This paper has shown that migration and remittances have statistically significant poverty reducing effects that appear to operate mainly through increases in per capita income of remittances-receiving countries. Indeed, cross-country regressions suggest that while in Latin America remittances generally have the effect of reducing inequality, the corresponding changes are generally small in magnitude. Thus, reductions in poverty are achieved mostly through the higher levels of income of migrant-sending households.

Complementing the above findings, our micro-econometric case studies suggest that the poverty and inequality reducing effects of remittances vary considerably across different Latin American countries. Thus, when no imputations are made for the income of remittances senders,

characteristics that reduce households' income generation capacity and increase their willingness to migrate - e.g. persistent unemployment, bad crops, etc. When this negative selection into migration driven by unobservable household characteristics prevail over positive selection effects, one could end up over-estimating households' "potential income" prior to migration, which could explain the poverty-increasing remittances effects obtained for Mexico. 


\section{WPS4249}

countries where recipients are concentrated at the bottom of the distribution of non-remittances income - e.g. Mexico, Paraguay, Ecuador, El Salvador and Guatemala - exhibit much higher reductions in poverty headcounts attributable to remittances. The fact that in those countries recipients are often found among relatively poorer households is arguably due to lower migration costs relative to household income, which in turn may be driven by the presence of well established migrant networks - associated with the countries' migratory histories - and/or by the relative proximity to the countries' main migrant destinations - e.g. as in the cases of Mexico and Paraguay.

It is important to note, however, that when imputations are made for the income of remittances senders prior to migration, the magnitude of the average poverty reducing effect of remittances becomes much smaller. Indeed, those estimates suggest that in Latin America and the Caribbean remittances have reduced poverty headcounts by about 0.4 percent for each percentage point increase in the remittances to GDP ratio, a result that is remarkably similar to the one obtained in our cross-country analysis. While these effects are far from negligible, and migration and remittances do appear to have helped improving the living conditions of a large number of poor Latin American households, the region's policy makers still face enormous challenges in terms of finding alternative means for addressing Latin America's high levels of moderate and extreme poverty. 


\section{WPS4249}

\section{REFERENCES}

Adams, R. (1989). Worker Remittances and Inequality in Rural Egypt. Economic Development and Cultural Change 38 (1), 45-71.

Adams, R. (2004). Remittances and Poverty in Guatemala. World Bank Policy Research Working Paper 3418.

Adams, R. (2006). Remittances and Poverty in Ghana. World Bank Policy Research Working Paper 3838 .

Adams, R., \& Page, J. (2005). Do International Migration and Remittances Reduce Poverty in Developing Countries? World Development 33 (10), 1645-1669.

Aggarwal, R., Demirguc-Kunt, A., \& Martinez-Peria, M. (2005). Do Workers' Remittances Promote Financial Development? Mimeo, The World Bank.

Arellano, M., \& Bond, S. (1991). Some Test of Specification for Panel Data: Montecarlo Evidence and an Application to Employment Equations. Review of Economic Studies 58 (2), 277-297.

Arellano, M., \& Bover, O. (1995). Another Look at the Instrumental Variable Estimation of ErrorComponents Models. Journal of Econometrics 68 (1), 29-51.

Banerjee, A., \& Duflo, E. (2003). Inequality and Growth: What Can the Data Say? Journal of Economic Growth 8 (3), 267-299.

Barham, B., \& Boucher, S. (1998). Migration, Remittances, and Inequality: Estimating the Net Effects of Migration on Income Distribution. Journal of Development Economics 55 (2), 307-331.

Barro, R., \& Lee, J. (2001). International Data on Educational Attainment: Updates and Implications. Oxford Economic Papers 53 (3), 541-63.

Blundell, R., \& Bond, S. (1998). Initial Conditions and Moment Restrictions in Dynamic Panel Data Models. Journal of Econometrics 87 (1), 115-143.

Dollar, D., \& Kraay, A. (2002): “Growth is Good for the Poor.” Journal of Economic Growth 7 (3), 195225.

Durlauf, S., \& Quah, D. (1999). The New Empirics of Economic Growth. In J. Taylor, \& M. Woorford (Eds.), Handbook of Macroeconomics (pp. 235-308). Amsterdam: North-Holland.

Forbes, K. (2000): “A Reassessment of the Relationship between Inequality and Growth." American Economic Review 90 (4), 869-887.

Foster, J., Greer, J., \& Thorbecke, E. (1984). A Class of Decomposable Poverty Measures. Econometrica 52 (3), 761-766. 


\section{WPS4249}

Gibrat, R. (1931). Les inégalités économiques. Paris: Recueil Sirey.

Global Economic Prospects (2006). Economic Implications of Remittances and Migration. Washington, DC: The World Bank.

Ibarraran, P., \& Lubotsky, D. (2005). Mexican Immigration and Self-Selection: New Evidence from the 2000 Mexican Census. NBER Working Paper 11456.

Kalecki, M. (1945). On the Gibrat Distribution. Econometrica 13 (2), 161-170.

Knowles, S. (2005). Inequality and Economic Growth: The Empirical Relationship Reconsidered in the Light of Comparable Data. Journal of Development Studies 41 (1), 135-159.

Lopez, H. (2004). Pro-Growth, Pro-Poor. Is There a Tradeoff? World Bank Policy Research Working Paper 3378.

Lopez, H., \& Serven, L. (2006). A Normal Relationship? Poverty, Growth and Inequality. World Bank Policy Research Working Paper 3814.

Lopez-Cordova, E. (2005). Globalization, Migration and Development: The Role of Mexican Migrant Remittances. Economia, Journal of the Latin American and Caribbean Economic Association 6 (1), 217-256.

Perotti, R. (1996). Growth, Income Distribution and Democracy. Journal of Economic Growth 1 (2), 149-187.

Perry, G., Arias, O., Lopez, H., Maloney, W., \& Serven, L. (2006). Poverty Reduction and Growth: Virtuous and Vicious Circles. Washington, DC: The World Bank.

Rodriguez, E. (1998). International Migration and Income Distribution in the Philippines. Economic Development and Cultural Change 46 (2), 329-350.

Rutherford, R. (1955). Income Distributions: A New Model. Econometrica 23 (3), 277-294.

Stark, O., Taylor, J., \& Yitzhaki, S. (1986). Remittances and Inequality. Economic Journal 96 (383), $722-740$.

Taylor, J., Mora, J., Adams, R., \& Lopez-Feldman, A. (2005). Remittances, Inequality, and Poverty: Evidence from Rural Mexico. Mimeo, University of California, Davis.

World Economic Outlook (2005). Globalization and External Imbalances. Washington, DC: International Monetary Fund.

Yang, D., \& Martinez, C. (2006). Remittances and Poverty in Migrants' Home Areas: Evidence from the Philippines. In C. Ozden, \& M. Schiff (Eds.), International Migration, Remittances and the Brain Drain (pp. 81-121). Washington, DC: The World Bank. 
Ziliak, J. (1997). Efficient Estimation with Panel Data when Instruments are Predetermined. Journal of Business and Economic Statistics 15 (4), 419-431. 
WPS4249

Table 1. The impact of remittances on growth

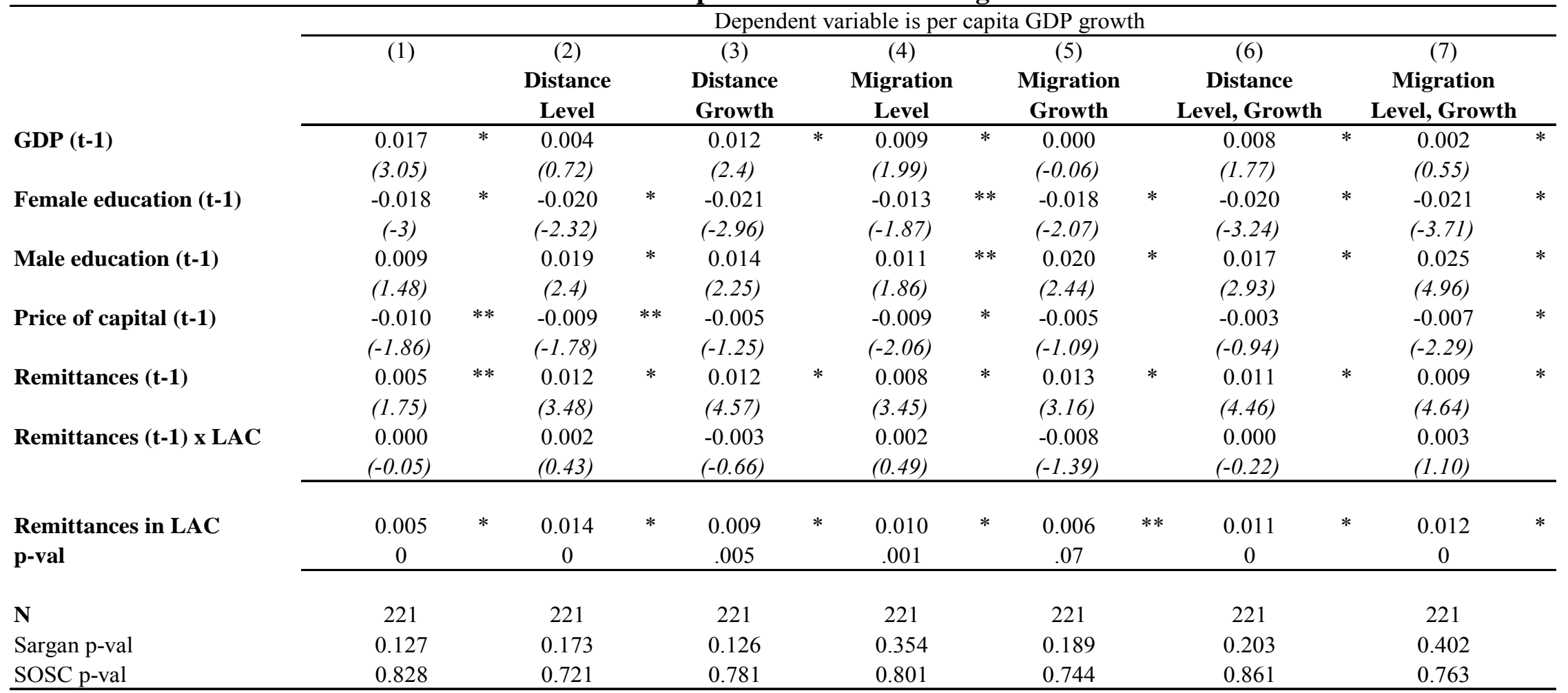

Notes: The table reports regression results with GDP growth as dependent variable; and GDP per capita (in logs), average years of secondary education of the female and male population, a measure of market distortion (given by the price of investment goods), remittances (as a percentage of GDP and in logs), and remittances interacted with a regional dummy for Latin America. t-stats in parenthesis; * indicates significance at the 5\% level and ** at the $10 \%$ level. All the explanatory variables are lagged one period. All regressions include a constant. The regressions are performed using the system GMM estimator as indicated by the heading in each column. The first column uses only lagged internal instruments. The second to seventh columns use lagged internal instruments for GDP per capita, average years of secondary education of the female and male population, and the measure of market distortion plus an external instrument which equals the per capita income level in the main migrant host countries weighted distance (Distance) or number of migrants (Migration). Level indicates that the external instrument is the value of the host countries per capita GDP series. Growth indicates that the external instrument is the growth rate of the host countries per capita GDP series. Level, growth combines the levels and growth instruments. Remittances in Latin America presents the value corresponding to the impact of Remittances on Latin American growth. 
WPS4249

Table 2. The impact of remittances on Latin American inequality

\begin{tabular}{|c|c|c|c|c|c|c|c|c|c|c|c|c|c|c|}
\hline \multirow[b]{3}{*}{ Gini (t-1) } & \multicolumn{13}{|c|}{ Dependent variable is changes in the log gini } & \\
\hline & $(1)$ & & $\begin{array}{c}(2) \\
\text { Distance } \\
\text { Level }\end{array}$ & & $\begin{array}{c}\text { (3) } \\
\text { Distance } \\
\text { Growth }\end{array}$ & & $\begin{array}{c}(4) \\
\text { Migration } \\
\text { Level }\end{array}$ & & $\begin{array}{c}\text { (5) } \\
\text { Migration } \\
\text { Growth }\end{array}$ & & $\begin{array}{c}\text { (6) } \\
\text { Distance } \\
\text { Level, Growth }\end{array}$ & & $\begin{array}{c}\text { (7) } \\
\text { Migration } \\
\text { Level, Growth }\end{array}$ & \\
\hline & $\begin{array}{c}-0.101 \\
(-19.59)\end{array}$ & $*$ & $\begin{array}{c}-0.110 \\
(-16.72)\end{array}$ & * & $\begin{array}{l}-0.102 \\
(-44)\end{array}$ & $*$ & $\begin{array}{c}-0.085 \\
(-23.43)\end{array}$ & * & $\begin{array}{c}-0.103 \\
(-41.78)\end{array}$ & * & $\begin{array}{c}-0.075 \\
(-15.07)\end{array}$ & * & $\begin{array}{c}-0.097 \\
(-22.94)\end{array}$ & * \\
\hline Female education (t-1) & $\begin{array}{l}0.024 \\
(9.55)\end{array}$ & $*$ & $\begin{array}{l}0.018 \\
(4.02)\end{array}$ & $*$ & $\begin{array}{l}0.014 \\
(4.05)\end{array}$ & $*$ & $\begin{array}{l}0.017 \\
(4.37)\end{array}$ & $*$ & $\begin{array}{l}0.022 \\
(5.3)\end{array}$ & $*$ & $\begin{array}{l}0.017 \\
(5.59)\end{array}$ & $*$ & $\begin{array}{l}0.018 \\
(4.06)\end{array}$ & $*$ \\
\hline Male education (t-1) & $\begin{array}{c}-0.029 \\
(-12.03)\end{array}$ & $*$ & $\begin{array}{l}-0.025 \\
(-5.10)\end{array}$ & $*$ & $\begin{array}{l}-0.023 \\
(-5.42)\end{array}$ & $*$ & $\begin{array}{l}-0.025 \\
(-6.24)\end{array}$ & $*$ & $\begin{array}{l}-0.030 \\
(-6.02)\end{array}$ & $*$ & $\begin{array}{l}-0.024 \\
(-5.66)\end{array}$ & $*$ & $\begin{array}{l}-0.024 \\
(-3.97)\end{array}$ & $*$ \\
\hline Price of capital ( $t-1)$ & $\begin{array}{l}-0.015 \\
(-4.36)\end{array}$ & $*$ & $\begin{array}{l}-0.007 \\
(-1.33)\end{array}$ & & $\begin{array}{l}-0.006 \\
(-1.67)\end{array}$ & & $\begin{array}{l}-0.014 \\
(-5.05)\end{array}$ & $*$ & $\begin{array}{l}-0.009 \\
(-2.69)\end{array}$ & $*$ & $\begin{array}{l}-0.004 \\
(-4.14)\end{array}$ & $*$ & $\begin{array}{l}-0.014 \\
(-5.16)\end{array}$ & $*$ \\
\hline Remittances (t-1) & $\begin{array}{l}0.007 \\
(5.43)\end{array}$ & $*$ & $\begin{array}{l}0.010 \\
(5.61)\end{array}$ & $*$ & $\begin{array}{l}0.011 \\
(9.92)\end{array}$ & $*$ & $\begin{array}{l}0.008 \\
(6.59)\end{array}$ & $*$ & $\begin{array}{l}0.009 \\
(6.51)\end{array}$ & $*$ & $\begin{array}{l}0.005 \\
(5.99)\end{array}$ & $*$ & $\begin{array}{l}0.008 \\
(6.10)\end{array}$ & * \\
\hline Remittances (t-1) x LAC & $\begin{array}{c}-0.014 \\
(-10.80) \\
\end{array}$ & * & $\begin{array}{l}-0.012 \\
(-3.03) \\
\end{array}$ & $*$ & $\begin{array}{l}-0.011 \\
(-9.41) \\
\end{array}$ & * & $\begin{array}{l}-0.011 \\
(-5.61) \\
\end{array}$ & $*$ & $\begin{array}{c}-0.012 \\
(-11.01) \\
\end{array}$ & $*$ & $\begin{array}{c}-0.011 \\
(-13.49) \\
\end{array}$ & $*$ & $\begin{array}{l}-0.013 \\
(-7.73) \\
\end{array}$ & $*$ \\
\hline $\begin{array}{l}\text { Remittances in LAC } \\
\text { p-val }\end{array}$ & $\begin{array}{r}-0.007 \\
0.000 \\
\end{array}$ & & $\begin{array}{r}-0.001 \\
0.600 \\
\end{array}$ & & $\begin{array}{l}0.000 \\
0.950 \\
\end{array}$ & & $\begin{array}{r}-0.003 \\
0.030 \\
\end{array}$ & & $\begin{array}{r}-0.003 \\
0.140 \\
\end{array}$ & & $\begin{array}{r}-0.006 \\
0.000 \\
\end{array}$ & & $\begin{array}{c}-0.006 \\
0.000 \\
\end{array}$ & \\
\hline $\begin{array}{l}\mathbf{N} \\
\text { Sargan p-val } \\
\text { SOSC p-val }\end{array}$ & $\begin{array}{c}85 \\
0.808 \\
0.306\end{array}$ & & $\begin{array}{c}85 \\
0.989 \\
0.214\end{array}$ & & $\begin{array}{c}85 \\
0.909 \\
0.188\end{array}$ & & $\begin{array}{c}85 \\
0.972 \\
0.239\end{array}$ & & $\begin{array}{c}85 \\
0.864 \\
0.240\end{array}$ & & $\begin{array}{c}85 \\
0.975 \\
0.275\end{array}$ & & $\begin{array}{c}85 \\
0.988 \\
0.276\end{array}$ & \\
\hline
\end{tabular}

Notes: The table reports regression results with changes in the log Gini as dependent variable; and the Gini (in logs), average years of secondary education of the female and male population, a measure of market distortion (given by the price of investment goods), remittances (as a percentage of GDP in logs), and remittances interacted with a regional dummy for Latin America. t-stats in parenthesis; * indicates significance at the 5\% level and ** at the $10 \%$ level. All the explanatory variables are lagged one period. All regressions include a constant. The regressions are performed using the system GMM estimator as indicated by the heading in each column. The first column uses only internal instruments. The second to seventh columns use lagged internal instruments for the Gini, average years of secondary education of the female and male population, and the measure of market distortion plus an external instrument which equals the per capita income level in the main migrant host countries weighted distance (Distance) or number of migrants (Migration). Level indicates that the external instrument is the value of the host countries per capita GDP series. Growth indicates that the external instrument is the growth rate of the host countries per capita GDP series. Level, growth combines the levels and growth instruments. Remittances in Latin America presents the value corresponding to the impact of Remittances on Latin American growth. 
WPS4249

Table 3. Poverty elasticity of remittances in Latin America

\begin{tabular}{|c|c|c|c|c|c|c|c|c|c|}
\hline \multicolumn{5}{|c|}{ GMM } & \multicolumn{5}{|c|}{ GMM, Distance, Level } \\
\hline & \multicolumn{4}{|c|}{ Gini Coefficient } & \multicolumn{5}{|c|}{ Gini Coefficient } \\
\hline$v / \mathbf{z}$ & 0.30 & 0.40 & 0.50 & 0.60 & $v / \mathbf{z}$ & 0.30 & 0.40 & 0.50 & 0.60 \\
\hline 6 & -1.17 & -0.68 & -0.46 & -0.33 & 6 & -0.94 & -0.51 & -0.32 & -0.20 \\
\hline 3 & -0.56 & -0.34 & -0.24 & -0.18 & 3 & -0.59 & -0.33 & -0.20 & -0.14 \\
\hline 2 & -0.32 & -0.20 & -0.15 & -0.12 & 2 & -0.40 & -0.23 & -0.15 & -0.10 \\
\hline 1.5 & -0.19 & -0.13 & -0.10 & -0.08 & 1.5 & -0.29 & -0.18 & -0.12 & -0.08 \\
\hline 1 & -0.07 & -0.06 & -0.05 & -0.04 & 1 & -0.16 & -0.11 & -0.08 & -0.06 \\
\hline \multicolumn{5}{|c|}{ GMM, Distance, Growth } & \multicolumn{5}{|c|}{ GMM, Migration, Level } \\
\hline & \multicolumn{4}{|c|}{ Gini Coefficient } & & \multicolumn{4}{|c|}{ Gini Coefficient } \\
\hline$v / \mathbf{z}$ & 0.30 & 0.40 & 0.50 & 0.60 & $v / \mathbf{z}$ & 0.30 & 0.40 & 0.50 & 0.60 \\
\hline 6 & -0.53 & -0.29 & -0.17 & -0.11 & 6 & -0.92 & -0.52 & -0.33 & -0.23 \\
\hline 3 & -0.35 & -0.19 & -0.12 & -0.08 & 3 & -0.52 & -0.30 & -0.19 & -0.14 \\
\hline 2 & -0.25 & -0.14 & -0.09 & -0.06 & 2 & -0.34 & -0.20 & -0.13 & -0.10 \\
\hline 1.5 & -0.18 & -0.11 & -0.07 & -0.05 & 1.5 & -0.23 & -0.14 & -0.10 & -0.07 \\
\hline 1 & -0.10 & -0.07 & -0.05 & -0.03 & 1 & -0.12 & -0.08 & -0.06 & -0.05 \\
\hline \multicolumn{5}{|c|}{ GMM, Migration, Growth } & \multicolumn{5}{|c|}{ GMM, Distance, Level \& Growth } \\
\hline & \multicolumn{4}{|c|}{ Gini Coefficient } & & \multicolumn{4}{|c|}{ Gini Coefficient } \\
\hline$v / \mathbf{z}$ & 0.30 & 0.40 & 0.50 & 0.60 & $v / \mathbf{z}$ & 0.30 & 0.40 & 0.50 & 0.60 \\
\hline 6 & -0.71 & -0.40 & -0.26 & -0.18 & 6 & -1.41 & -0.80 & -0.52 & -0.37 \\
\hline 3 & -0.37 & -0.22 & -0.15 & -0.11 & 3 & -0.74 & -0.44 & -0.29 & -0.21 \\
\hline 2 & -0.23 & -0.14 & -0.10 & -0.07 & 2 & -0.46 & -0.28 & -0.19 & -0.14 \\
\hline 1.5 & -0.15 & -0.10 & -0.07 & -0.05 & 1.5 & -0.30 & -0.19 & -0.14 & -0.11 \\
\hline 1 & -0.07 & -0.05 & -0.04 & -0.03 & 1 & -0.14 & -0.10 & -0.08 & -0.06 \\
\hline
\end{tabular}

GMM, Migration, Level \& Growth

\begin{tabular}{ccccc} 
& \multicolumn{4}{c}{ Gini Coefficient } \\
\cline { 2 - 5 }$v / \mathbf{z}$ & $\mathbf{0 . 3 0}$ & $\mathbf{0 . 4 0}$ & $\mathbf{0 . 5 0}$ & $\mathbf{0 . 6 0}$ \\
6 & -1.49 & -0.84 & -0.55 & -0.38 \\
3 & -0.80 & -0.47 & -0.31 & -0.22 \\
2 & -0.49 & -0.30 & -0.21 & -0.15 \\
1.5 & -0.33 & -0.21 & -0.15 & -0.11 \\
1 & -0.15 & -0.11 & -0.09 & -0.07
\end{tabular}

Notes: The table reports the estimated poverty elasticities of remittances/GDP for different values of the Gini coefficient and of per capita income to the poverty line $v / z$. It assumes an initial level of remittances of 10 percent of GDP 


\section{Table 4. Sources of Household Survey Data}

\begin{tabular}{lll}
\hline \multicolumn{1}{c}{ Country } & Year & \\
\hline Bolivia & 2002 & Encuesta de Hogares, MECOVI \\
Ecuador & 2004 & Sistema Integrado de Encuestas de Hogares, INEC \\
El Salvador & 2000 & Encuesta de Hogares de Propositos Multiples, MECOVI \\
Guatemala & 2000 & Encuesta Nacional sobre Condiciones de Vida (ENCOVI) \\
Haiti & 2001 & Les Conditions de Vie en Haiti, IHSI/Fafo/PNUD \\
Honduras & 2002 & Encuesta Permanente de Hogares de Propositos Multiples, MECOVI \\
Mexico & 2002 & Encuesta Nacional de Ingresos y Gastos de los Hogares, INEGI \\
Nicaragua & 2001 & Encuesta Nacional de Hogares sobre Medicion de Nivel de Vida, INEC \\
Paraguay & 2003 & Encuesta Permanente de Hogares, Direccion General de Estadistica \\
Peru & 2002 & Encuesta Nacional de Hogares, INEI \\
\hline
\end{tabular}


Table 5: Inequality Decompositions for Latin American and Caribbean Countries

\begin{tabular}{|c|c|c|c|c|c|c|}
\hline Country & $\begin{array}{l}\text { Share in Total } \\
\text { Income }\end{array}$ & Gini Coefficient & $\begin{array}{c}\text { Gini correlation } \\
\text { with Total } \\
\text { Income } \\
\end{array}$ & $\begin{array}{c}\text { Contribution to } \\
\text { Gini of Total } \\
\text { Income } \\
\end{array}$ & $\begin{array}{l}\% \text { Share in Gini } \\
\text { of Total Income }\end{array}$ & $\begin{array}{c}\text { Marginal Effect } \\
\text { on Gini of Total } \\
\text { Income* }\end{array}$ \\
\hline \multicolumn{7}{|l|}{$\overline{\text { Bolivia (2002) }}$} \\
\hline Non-Remittances Income & 0.985 & 0.557 & 0.991 & 0.544 & 0.981 & -0.004 \\
\hline Remittances & 0.015 & 0.990 & 0.728 & 0.011 & 0.019 & 0.004 \\
\hline Total Income & 1.000 & 0.555 & 1.000 & 0.555 & 1.000 & \\
\hline \multicolumn{7}{|l|}{ Ecuador (2004) } \\
\hline Non-Remittances Income & 0.964 & 0.505 & 0.980 & 0.477 & 0.957 & -0.007 \\
\hline Remittances & 0.036 & 0.969 & 0.620 & 0.022 & 0.043 & 0.007 \\
\hline Total Income & 1.000 & 0.499 & 1.000 & 0.499 & 1.000 & \\
\hline \multicolumn{7}{|l|}{$\overline{\text { El Salvador (2000) }}$} \\
\hline Non-Remittances Income & 0.941 & 0.514 & 0.972 & 0.470 & 0.967 & 0.026 \\
\hline Remittances & 0.059 & 0.910 & 0.303 & 0.016 & 0.033 & -0.026 \\
\hline Total Income & 1.000 & 0.486 & 1.000 & 0.486 & 1.000 & \\
\hline \multicolumn{7}{|l|}{$\overline{\text { Guatemala (2000) }}$} \\
\hline Non-Remittances Income & 0.969 & 0.596 & 0.986 & 0.569 & 0.973 & 0.004 \\
\hline Remittances & 0.031 & 0.958 & 0.541 & 0.016 & 0.027 & -0.004 \\
\hline Total Income & 1.000 & 0.586 & 1.000 & 0.586 & 1.000 & \\
\hline \multicolumn{7}{|l|}{ Haiti (2001) } \\
\hline Non-Remittances Income & 0.794 & 0.670 & 0.926 & 0.493 & 0.736 & -0.058 \\
\hline Remittances & 0.206 & 0.916 & 0.937 & 0.177 & 0.264 & 0.058 \\
\hline Total Income & 1.000 & 0.669 & 1.000 & 0.669 & 1.000 & \\
\hline \multicolumn{7}{|l|}{ Honduras (2002) } \\
\hline Non-Remittances Income & 0.933 & 0.572 & 0.971 & 0.518 & 0.927 & -0.006 \\
\hline Remittances & 0.067 & 0.954 & 0.634 & 0.041 & 0.073 & 0.006 \\
\hline Total Income & 1.000 & 0.559 & 1.000 & 0.559 & 1.000 & \\
\hline \multicolumn{7}{|l|}{$\overline{\text { Mexico (2002) }}$} \\
\hline Non-Remittances Income & 0.980 & 0.491 & 0.987 & 0.475 & 0.988 & 0.008 \\
\hline Remittances & 0.020 & 0.976 & 0.289 & 0.006 & 0.012 & -0.008 \\
\hline Total Income & 1.000 & 0.481 & 1.000 & 0.481 & 1.000 & \\
\hline \multicolumn{7}{|l|}{$\overline{\text { Nicaragua (2001) }}$} \\
\hline Non-Remittances Income & 0.976 & 0.517 & 0.992 & 0.501 & 0.966 & -0.010 \\
\hline Remittances & 0.024 & 0.959 & 0.773 & 0.018 & 0.034 & 0.010 \\
\hline Total Income & 1.000 & 0.518 & 1.000 & 0.518 & 1.000 & \\
\hline \multicolumn{7}{|l|}{$\overline{\text { Paraguay (2003) }}$} \\
\hline Non-Remittances Income & 0.986 & 0.520 & 0.995 & 0.510 & 0.988 & 0.002 \\
\hline Remittances & 0.014 & 0.985 & 0.437 & 0.006 & 0.012 & -0.002 \\
\hline Total Income & 1.000 & 0.516 & 1.000 & 0.516 & 1.000 & \\
\hline \multicolumn{7}{|l|}{ Peru (2002) } \\
\hline Non-Remittances Income & 0.989 & 0.476 & 0.992 & 0.467 & 0.980 & -0.009 \\
\hline Remittances & 0.011 & 0.989 & 0.865 & 0.009 & 0.020 & 0.009 \\
\hline Total Income & 1.000 & 0.476 & 1.000 & 0.476 & 1.000 & \\
\hline
\end{tabular}

* Effects of a $1 \%$ increase in per capita income from different sources on the Gini coefficient of Total Income. 


\section{WPS4249}

Table 6: Remittances-Receiving Households in the Income Distribution for various Income Definitions

Remittances and Reported Non-Remittances Income

\begin{tabular}{|c|c|c|c|c|c|c|c|c|c|c|}
\hline NR Income Quintiles & Mexico (2002) & Guatemala (2000) & El Salvador (2000) & Paraguay (2003) & Honduras (2002) & Bolivia (2002) & Ecuador (2004) & Haiti (2001) & Peru (2002) & Nicaragua (2001) \\
\hline 1 & 60.66 & 31.77 & 33.96 & 42.09 & 26.76 & 28.79 & 34.70 & 22.65 & 5.79 & 12.05 \\
\hline 2 & 14.86 & 15.25 & 19.35 & 16.64 & 16.02 & 16.79 & 18.49 & 16.76 & 13.17 & 14.51 \\
\hline 3 & 12.43 & 19.55 & 15.37 & 18.08 & 18.76 & 13.61 & 14.65 & 17.37 & 17.31 & 18.30 \\
\hline 4 & 7.89 & 15.87 & 16.59 & 14.86 & 21.09 & 17.20 & 15.89 & 18.26 & 24.22 & 22.63 \\
\hline 5 & 4.05 & 17.58 & 14.66 & 8.32 & 17.42 & 23.59 & 16.24 & 24.79 & 39.35 & 32.58 \\
\hline
\end{tabular}

Remittances and Imputed Non-Remittances Income (Counterfactual Scenario)

\begin{tabular}{|c|c|c|c|c|c|c|c|c|c|c|}
\hline NR Income Quintiles & Mexico (2002) & Guatemala (2000) & El Salvador (2000) & Paraguay (2003) & Honduras (2002) & Bolivia (2002) & Ecuador (2004) & Haiti (2001) & Peru (2002) & Nicaragua (2001) \\
\hline 1 & 25.12 & 21.54 & 18.29 & 21.14 & 10.48 & 17.26 & 15.74 & 15.26 & 1.76 & 10.34 \\
\hline 2 & 26.68 & 20.98 & 21.94 & 23.87 & 20.31 & 20.69 & 19.53 & 16.61 & 7.48 & 14.71 \\
\hline 3 & 22.39 & 16.29 & 20.05 & 20.92 & 23.13 & 17.66 & 19.72 & 17.85 & 16.22 & 18.50 \\
\hline 4 & 17.63 & 16.48 & 20.47 & 19.83 & 23.21 & 18.83 & 22.03 & 20.90 & 27.35 & 22.36 \\
\hline 5 & 8.11 & 24.70 & 19.24 & 14.28 & 22.89 & 25.58 & 23.09 & 29.43 & 47.04 & 34.20 \\
\hline
\end{tabular}

Remittances and Total Income (including remittances)

\begin{tabular}{|c|c|c|c|c|c|c|c|c|c|c|}
\hline Total Income Quintiles & Mexico (2002) & Guatemala (2000) & El Salvador (2000) & Paraguay (2003) & Honduras (2002) & Bolivia (2002) & Ecuador (2004) & Haiti (2001) & Peru (2002) & Nicaragua (2001) \\
\hline 1 & 26.38 & 8.77 & 12.43 & 18.90 & 3.95 & 12.28 & 6.93 & 6.12 & 0.38 & 8.40 \\
\hline 2 & 23.42 & 14.23 & 21.70 & 20.32 & 13.17 & 15.16 & 13.10 & 13.83 & 6.06 & 12.16 \\
\hline 3 & 21.73 & 25.77 & 21.76 & 20.45 & 21.65 & 16.65 & 17.65 & 19.74 & 15.67 & 18.26 \\
\hline 4 & 16.39 & 26.76 & 22.90 & 21.30 & 29.45 & 19.89 & 27.78 & 24.08 & 26.10 & 24.71 \\
\hline 5 & 11.85 & 24.20 & 21.19 & 19.11 & 31.87 & 36.07 & 35.49 & 36.26 & 51.63 & 36.54 \\
\hline
\end{tabular}




\section{WPS4249}

Table 7: Remittances-Receiving Households in the Distribution of Household Assets and Education

Remittances and HH Assets Index

\begin{tabular}{|c|c|c|c|c|c|c|c|c|c|c|}
\hline HH Assets Quintiles & Mexico (2002) & Guatemala (2000) & El Salvador (2000) & Paraguay (2003) & Honduras (2002) & Bolivia (2002) & Ecuador (2004) & Haiti (2001) & Peru (2002) & Nicaragua (2001) \\
\hline 1 & 17.01 & 13.46 & 11.00 & 12.98 & $\mathrm{~N} / \mathrm{A}$ & $\mathrm{N} / \mathrm{A}$ & $\mathrm{N} / \mathrm{A}$ & 10.00 & 2.09 & 6.46 \\
\hline 2 & 28.52 & 16.86 & 16.06 & 24.65 & N/A & $\mathrm{N} / \mathrm{A}$ & $\mathrm{N} / \mathrm{A}$ & 12.98 & 2.52 & 9.35 \\
\hline 3 & 23.76 & 19.95 & 22.74 & 23.39 & N/A & $\mathrm{N} / \mathrm{A}$ & $\mathrm{N} / \mathrm{A}$ & 15.44 & 8.97 & 14.32 \\
\hline 4 & 20.86 & 22.77 & 26.04 & 20.13 & $\mathrm{~N} / \mathrm{A}$ & $\mathrm{N} / \mathrm{A}$ & $\mathrm{N} / \mathrm{A}$ & 23.30 & 24.50 & 26.76 \\
\hline 5 & 9.97 & 27.74 & 24.23 & 18.75 & N/A & $\mathrm{N} / \mathrm{A}$ & $\mathrm{N} / \mathrm{A}$ & 39.51 & 62.09 & 43.50 \\
\hline
\end{tabular}

Note: HH Assets Index constructed using First Principal Components technique.

Remittances and Education

(\% of $\mathrm{HHs}$ receiving remittances by average years of education of adults)

\begin{tabular}{|c|c|c|c|c|c|c|c|c|c|c|}
\hline Years of Education & Mexico (2002) & Guatemala (2000) & El Salvador (2000) & Paraguay (2003) & Honduras (2002) & Bolivia (2002) & Ecuador (2004) & Haiti (2001) & Peru (2002) & Nicaragua (2001) \\
\hline 0 & 10.88 & 8.24 & 23.16 & 7.65 & 7.96 & 6.88 & 5.87 & 18.59 & 1.76 & 10.87 \\
\hline $1-4$ & 13.11 & 6.42 & 18.00 & 4.79 & 6.97 & 2.08 & 2.34 & 25.17 & 0.65 & 8.17 \\
\hline $5-7$ & 6.46 & 6.29 & 19.77 & 4.20 & 12.66 & 2.35 & 3.09 & 37.99 & 0.89 & 14.34 \\
\hline $8-11$ & 3.09 & 6.32 & 19.68 & 3.19 & 16.11 & 3.34 & 3.77 & 44.89 & 3.48 & 24.19 \\
\hline $12+$ & 2.06 & 4.54 & 17.52 & 2.80 & 12.72 & 4.71 & 5.23 & 57.12 & 5.35 & 29.46 \\
\hline All HHs & 5.82 & 6.56 & 19.32 & 3.83 & 10.88 & 3.47 & 3.97 & 27.21 & 2.82 & 15.64 \\
\hline
\end{tabular}


WPS4249

Table 8: Remittances and Inequality in Counterfactual Scenario of No-Migration

\begin{tabular}{|c|c|c|c|c|}
\hline \multirow[b]{2}{*}{ Country } & \multicolumn{4}{|c|}{ Gini Coefficient } \\
\hline & \multicolumn{2}{|c|}{$\begin{array}{l}\text { Reported Non-Remittances } \\
\text { Income }\end{array}$} & \multicolumn{2}{|c|}{$\begin{array}{c}\text { Imputed Non-Remittances } \\
\text { Income }\end{array}$} \\
\hline \multicolumn{5}{|l|}{ Bolivia (2002) } \\
\hline Before Remittances & 0.557 & & 0.556 & \\
\hline 95\% Confidence Interval & & & $(0.553 ; 0.561)$ & \\
\hline After Remittances & 0.555 & & 0.555 & \\
\hline \% Change (elasticity w.r.t rem/inc) & -0.446 & $(-0.293)$ & -0.267 & $(-0.175)$ \\
\hline \multicolumn{5}{|l|}{ Ecuador (2004) } \\
\hline Before Remittances & 0.505 & & 0.501 & \\
\hline 95\% Confidence Interval & & & $(0.500 ; 0.503)$ & \\
\hline After Remittances & 0.499 & & 0.499 & \\
\hline \% Change (elasticity w.r.t rem/inc) & -1.245 & $(-0.333)$ & -0.457 & $(-0.122)$ \\
\hline \multicolumn{5}{|l|}{ El Salvador (2000) } \\
\hline Before Remittances & 0.514 & & 0.497 & \\
\hline 95\% Confidence Interval & & & $(0.494 ; 0.501)$ & \\
\hline After Remittances & 0.486 & & 0.486 & \\
\hline \% Change (elasticity w.r.t rem/inc) & -5.370 & $(-0.856)$ & -2.133 & $(-0.340)$ \\
\hline \multicolumn{5}{|l|}{ Guatemala (2000) } \\
\hline Before Remittances & 0.596 & & 0.603 & \\
\hline $95 \%$ Confidence Interval & & & $(0.596 ; 0.615)$ & \\
\hline After Remittances & 0.586 & & 0.586 & \\
\hline \% Change (elasticity w.r.t rem/inc) & -1.761 & $(-0.550)$ & -2.901 & $(-0.907)$ \\
\hline \multicolumn{5}{|l|}{ Haiti (2001) } \\
\hline Before Remittances & 0.670 & & 0.725 & \\
\hline 95\% Confidence Interval & & & $(0.703 ; 0.756)$ & \\
\hline After Remittances & 0.669 & & 0.669 & \\
\hline \% Change (elasticity w.r.t rem/inc) & -0.086 & $(-0.003)$ & -7.666 & $(-0.295)$ \\
\hline \multicolumn{5}{|l|}{ Honduras (2002) } \\
\hline Before Remittances & 0.572 & & 0.565 & \\
\hline 95\% Confidence Interval & & & $(0.564 ; 0.567)$ & \\
\hline After Remittances & 0.559 & & 0.559 & \\
\hline \% Change (elasticity w.r.t rem/inc) & -2.321 & $(-0.323)$ & -1.111 & $(-0.155)$ \\
\hline \multicolumn{5}{|l|}{ Mexico (2002) } \\
\hline Before Remittances & 0.491 & & 0.477 & \\
\hline 95\% Confidence Interval & & & $(0.477 ; 0.478)$ & \\
\hline After Remittances & 0.481 & & 0.481 & \\
\hline \% Change (elasticity w.r.t rem/inc) & -2.125 & $(-1.041)$ & 0.748 & $(0.366)$ \\
\hline \multicolumn{5}{|l|}{ Nicaragua (2001) } \\
\hline Before Remittances & 0.517 & & 0.528 & \\
\hline 95\% Confidence Interval & & & $(0.519 ; 0.539)$ & \\
\hline After Remittances & 0.518 & & 0.518 & \\
\hline \% Change (elasticity w.r.t rem/inc) & 0.260 & $(0.106)$ & -1.828 & $(-0.744)$ \\
\hline \multicolumn{5}{|l|}{ Paraguay (2003) } \\
\hline Before Remittances & 0.520 & & 0.515 & \\
\hline 95\% Confidence Interval & & & $(0.514 ; 0.517)$ & \\
\hline After Remittances & 0.516 & & 0.516 & \\
\hline \% Change (elasticity w.r.t rem/inc) & -0.734 & $(-0.517)$ & 0.230 & $(0.162)$ \\
\hline \multicolumn{5}{|l|}{ Peru (2002) } \\
\hline Before Remittances & 0.476 & & 0.478 & \\
\hline 95\% Confidence Interval & & & $(0.476 ; 0.481)$ & \\
\hline After Remittances & 0.476 & & 0.476 & \\
\hline \% Change (elasticity w.r.t rem/inc) & 0.086 & $(0.077)$ & -0.333 & $(-0.299)$ \\
\hline
\end{tabular}

Source: Author's calculations based on Household Surveys for each country. 
WPS4249

Table 9: Remittances and Poverty Headcount in Counterfactual Scenario of No-Migration

\begin{tabular}{|c|c|c|c|c|c|c|c|c|}
\hline \multirow{3}{*}{ Country } & \multicolumn{8}{|c|}{ Poverty Headcount (\%) } \\
\hline & \multicolumn{4}{|c|}{ Less than US\$ 1 (PPP) a day } & \multicolumn{4}{|c|}{ Less than US\$ 2 (PPP) a day } \\
\hline & \multicolumn{2}{|c|}{$\begin{array}{l}\text { Reported Non-Remittances } \\
\text { Income }\end{array}$} & \multicolumn{2}{|c|}{$\begin{array}{l}\text { Imputed Non-Remittances } \\
\text { Income }\end{array}$} & \multicolumn{2}{|c|}{$\begin{array}{l}\text { Reported Non-Remittances } \\
\text { Income }\end{array}$} & \multicolumn{2}{|c|}{$\begin{array}{l}\text { Imputed Non-Remittances } \\
\text { Income }\end{array}$} \\
\hline \multicolumn{9}{|l|}{ Bolivia (2002) } \\
\hline Before Remittances & 18.400 & & 17.999 & & 35.261 & & 35.052 & \\
\hline $95 \%$ Confidence Interval & & & $(17.842 ; 18.184)$ & & & & $(34.824 ; 35.279)$ & \\
\hline After Remittances & 17.764 & & 17.764 & & 34.674 & & 34.674 & \\
\hline \% Change (elasticity w.r.t rem/inc) & -3.457 & $(-2.270)$ & -1.306 & $(-0.857)$ & -1.665 & $(-1.093)$ & -1.078 & $(-0.708)$ \\
\hline \multicolumn{9}{|l|}{ Ecuador (2004) } \\
\hline Before Remittances & 12.531 & & 11.665 & & 28.849 & & 28.082 & \\
\hline $95 \%$ Confidence Interval & & & $(11.594 ; 11.741)$ & & & & $(27.960 ; 28.221)$ & \\
\hline After Remittances & 11.198 & & 11.198 & & 27.147 & & 27.147 & \\
\hline \% Change (elasticity w.r.t rem/inc) & -10.638 & $(-2.849)$ & -4.003 & $(-1.072)$ & -5.900 & $(-1.580)$ & -3.330 & $(-0.892)$ \\
\hline \multicolumn{9}{|l|}{$\overline{\text { El Salvador (2000) }}$} \\
\hline Before Remittances & 12.116 & & 8.215 & & 23.743 & & 20.055 & \\
\hline $95 \%$ Confidence Interval & & & $(8.077 ; 8.375)$ & & & & $(19.824 ; 20.311)$ & \\
\hline After Remittances & 7.700 & & 7.700 & & 18.607 & & 18.607 & \\
\hline \% Change (elasticity w.r.t rem/inc) & -36.448 & $(-5.813)$ & -6.269 & $(-1.000)$ & -21.632 & $(-3.450)$ & -7.220 & $(-1.152)$ \\
\hline \multicolumn{9}{|l|}{ Guatemala $(2000)$} \\
\hline Before Remittances & 24.413 & & 23.630 & & 41.715 & & 41.379 & \\
\hline $95 \%$ Confidence Interval & & & $(23.335 ; 23.931)$ & & & & $(41.055 ; 41.710)$ & \\
\hline After Remittances & 21.578 & & 21.578 & & 39.087 & & 39.087 & \\
\hline \% Change (elasticity w.r.t rem/inc) & -11.613 & $(-3.630)$ & -8.684 & $(-2.714)$ & -6.300 & $(-1.969)$ & -5.539 & $(-1.731)$ \\
\hline \multicolumn{9}{|l|}{ Haiti (2001) } \\
\hline Before Remittances & 60.229 & & 57.541 & & 76.343 & & 74.376 & \\
\hline $95 \%$ Confidence Interval & & & $(56.929 ; 58.138)$ & & & & $(73.793 ; 74.992)$ & \\
\hline After Remittances & 53.425 & & 53.425 & & 71.414 & & 71.414 & \\
\hline \% Change (elasticity w.r.t rem/inc) & -11.297 & $(-0.435)$ & -7.153 & $(-0.276)$ & -6.456 & $(-0.249)$ & -3.982 & $(-0.153)$ \\
\hline \multicolumn{9}{|l|}{ Honduras (2002) } \\
\hline Before Remittances & 18.681 & & 16.715 & & 34.772 & & 33.155 & \\
\hline $95 \%$ Confidence Interval & & & $(16.608 ; 16.820)$ & & & & $(32.993 ; 33.307)$ & \\
\hline After Remittances & 16.155 & & 16.155 & & 31.731 & & 31.731 & \\
\hline \% Change (elasticity w.r.t rem/inc) & -13.522 & $(-1.883)$ & -3.350 & $(-0.467)$ & -8.746 & $(-1.218)$ & -4.295 & $(-0.598)$ \\
\hline \multicolumn{9}{|l|}{ Mexico (2002) } \\
\hline Before Remittances & 5.268 & & 3.079 & & 15.029 & & 12.603 & \\
\hline $95 \%$ Confidence Interval & & & $(3.019 ; 3.145)$ & & & & $(12.480 ; 12.731)$ & \\
\hline After Remittances & 3.165 & & 3.165 & & 12.695 & & 12.695 & \\
\hline \% Change (elasticity w.r.t rem/inc) & -39.920 & $(-19.561)$ & 2.793 & (1.369) & -15.530 & $(-7.610)$ & 0.730 & $(0.358)$ \\
\hline \multicolumn{9}{|l|}{ Nicaragua (2001) } \\
\hline Before Remittances & 8.763 & & 8.226 & & 23.323 & & 22.848 & \\
\hline $95 \%$ Confidence Interval & & & $(8.012 ; 8.528)$ & & & & $(22.427 ; 23.345)$ & \\
\hline After Remittances & 8.260 & & 8.260 & & 22.552 & & 22.552 & \\
\hline \% Change (elasticity w.r.t rem/inc) & -5.740 & $(-2.334)$ & 0.413 & $(0.168)$ & -3.306 & $(-1.344)$ & -1.296 & $(-0.527)$ \\
\hline \multicolumn{9}{|l|}{ Paraguay (2003) } \\
\hline Before Remittances & 6.839 & & 6.066 & & 16.188 & & 15.373 & \\
\hline $95 \%$ Confidence Interval & & & $(5.999 ; 6.145)$ & & & & $(15.256 ; 15.521)$ & \\
\hline After Remittances & 6.057 & & 6.057 & & 15.333 & & 15.333 & \\
\hline \% Change (elasticity w.r.t rem/inc) & -11.434 & $(-8.053)$ & -0.148 & $(-0.104)$ & -5.282 & $(-3.720)$ & -0.260 & $(-0.183)$ \\
\hline \multicolumn{9}{|l|}{ Peru (2002) } \\
\hline Before Remittances & 4.193 & & 4.186 & & 15.644 & & 15.555 & \\
\hline $95 \%$ Confidence Interval & & & $(4.186 ; 4.192)$ & & & & $(15.533 ; 15.888)$ & \\
\hline After Remittances & 4.185 & & 4.185 & & 15.539 & & 15.539 & \\
\hline$\%$ Change (elasticity w.r.t rem/inc) & -0.191 & $(-0.172)$ & -0.024 & $(-0.021)$ & -0.671 & $(-0.603)$ & -0.103 & $(-0.092)$ \\
\hline
\end{tabular}




\section{WPS4249}

Table 10: Remittances and Poverty Gap in Counterfactual Scenario of No-Migration

\begin{tabular}{|c|c|c|c|c|c|c|c|c|}
\hline \multirow{3}{*}{ Country } & \multicolumn{4}{|c|}{ Poverty Gap } & \multicolumn{4}{|c|}{ Squared Poverty Gap, \% Change (elasticity w.r.t rem/inc) } \\
\hline & \multicolumn{2}{|c|}{$\begin{array}{l}\text { Reported Non-Remittances } \\
\text { Income }\end{array}$} & \multicolumn{2}{|c|}{ Imputed Non-Remittances Income } & \multicolumn{2}{|c|}{$\begin{array}{c}\text { Reported Non-Remittances } \\
\text { Income }\end{array}$} & \multicolumn{2}{|c|}{ Imputed Non-Remittances Income } \\
\hline & $\%$ Change & Elasticity & $\%$ Change & Elasticity & $\%$ Change & Elasticity & $\%$ Change & Elasticity \\
\hline \multicolumn{9}{|l|}{$\overline{\text { Bolivia - } 2002}$} \\
\hline Less than US\$ 1 (PPP) a day & -0.83 & $(-0.547)$ & $(-0.37 ; 0.75)$ & $(-0.24 ; 0.49)$ & -1.48 & $(-0.970)$ & $(-0.27 ; 1.08)$ & $(-0.18 ; 0.71)$ \\
\hline Less than US\$2 (PPP) a day & -1.12 & $(-0.735)$ & $(-0.39 ; 0.39)$ & $(-0.26 ; 0.26)$ & -1.88 & $(-1.232)$ & $(-0.56 ; 0.57)$ & $(-0.37 ; 0.37)$ \\
\hline \multicolumn{9}{|l|}{ Ecuador - 2004} \\
\hline Less than US\$ 1 (PPP) a day & -9.31 & $(-2.493)$ & $(-1.21 ;-0.49)$ & $(-0.32 ;-0.13)$ & -18.42 & $(-4.932)$ & $(-2.89 ;-1.67)$ & $(-0.77 ;-0.45)$ \\
\hline Less than US\$2 (PPP) a day & -4.17 & $(-1.118)$ & $(-0.91 ;-0.23)$ & $(-0.24 ;-0.06)$ & -8.55 & $(-2.289)$ & $(-1.52 ;-0.77)$ & $(-0.41 ;-0.21)$ \\
\hline \multicolumn{9}{|l|}{ El Salvador - 2000} \\
\hline Less than US\$ 1 (PPP) a day & -16.56 & $(-2.641)$ & $(1.36 ; 3.94)$ & $(0.22 ; 0.63)$ & -36.44 & $(-5.812)$ & $(2.59 ; 5.73)$ & $(0.41 ; 0.91)$ \\
\hline Less than US\$ 2 (PPP) a day & -15.64 & $(-2.494)$ & $(-0.07 ; 0.67)$ & $(-0.01 ; 0.11)$ & -26.74 & $(-4.265)$ & $(0.74 ; 3.04)$ & $(0.12 ; 0.49)$ \\
\hline \multicolumn{9}{|l|}{ Guatemala - 2000} \\
\hline Less than US\$ 1 (PPP) a day & -6.24 & $(-1.950)$ & $(-4.05 ;-2.43)$ & $(-1.27 ;-0.76)$ & -11.60 & $(-3.625)$ & $(-6.98 ;-4.76)$ & $(-2.18 ;-1.49)$ \\
\hline Less than US\$2 (PPP) a day & -4.41 & $(-1.379)$ & $(-2.91 ;-1.84)$ & $(-0.91 ;-0.58)$ & -8.19 & $(-2.561)$ & $(-5.39 ;-3.66)$ & $(-1.69 ;-1.14)$ \\
\hline \multicolumn{9}{|l|}{ Haiti - 2001} \\
\hline Less than US\$ 1 (PPP) a day & -5.29 & $(-0.204)$ & $(-3.39 ;-1.96)$ & $(-0.13 ;-0.08)$ & -9.24 & $(-0.356)$ & $(-5.28 ;-3.36)$ & $(-0.20 ;-0.13)$ \\
\hline Less than US\$ 2 (PPP) a day & -4.99 & $(-0.192)$ & $(-3.46 ;-2.48)$ & $(-0.13 ;-0.10)$ & -8.02 & $(-0.309)$ & $(-5.31 ;-3.72)$ & $(-0.21 ;-0.14)$ \\
\hline \multicolumn{9}{|l|}{ Honduras - 2002} \\
\hline Less than US\$ 1 (PPP) a day & -10.64 & $(-1.482)$ & $(0.24 ; 1.23)$ & $(0.03 ; 0.17)$ & -21.55 & $(-3.001)$ & $(0.44 ; 1.79)$ & $(0.06 ; 0.25)$ \\
\hline Less than US\$ 2 (PPP) a day & -4.97 & $(-0.693)$ & $(0.20 ; 1.03)$ & $(0.03 ; 0.14)$ & -9.86 & $(-1.373)$ & $(0.33 ; 1.33)$ & $(0.05 ; 0.19)$ \\
\hline \multicolumn{9}{|l|}{ Mexico - 2002} \\
\hline Less than US\$ $1(\mathrm{PPP})$ a day & -45.68 & $(-22.384)$ & $(-0.84 ; 2.17)$ & $(-0.41 ; 1.06)$ & -72.54 & $(-35.543)$ & $(-1.19 ; 2.47)$ & $(-0.58 ; 1.21)$ \\
\hline Less than US\$ 2 (PPP) a day & -19.08 & $(-9.351)$ & $(-0.30 ; 1.54)$ & $(-0.15 ; 0.76)$ & -36.48 & $(-17.876)$ & $(-0.11 ; 2.55)$ & $(-0.05 ; 1.25)$ \\
\hline \multicolumn{9}{|l|}{ Nicaragua - 2001} \\
\hline Less than US\$ $1(\mathrm{PPP})$ a day & -3.88 & $(-1.579)$ & $(-0.91 ; 3.31)$ & $(-0.37 ; 1.35)$ & -8.58 & $(-3.488)$ & $(-0.19 ; 5.03)$ & $(-0.08 ; 2.05)$ \\
\hline Less than US\$2 (PPP) a day & -1.31 & $(-0.531)$ & $(-0.70 ; 1.92)$ & $(-0.29 ; 0.78)$ & -3.47 & $(-1.411)$ & $(-0.40 ; 3.31)$ & $(-0.16 ; 1.35)$ \\
\hline \multicolumn{9}{|l|}{ Paraguay - 2003} \\
\hline Less than US\$ 1 (PPP) a day & -9.11 & $(-6.419)$ & $(-1.57 ; 0.27)$ & $(-1.11 ; 0.19)$ & -18.74 & $(-13.201)$ & $(-1.98 ; 0.51)$ & $(-1.39 ; 0.36)$ \\
\hline Less than US\$2 (PPP) a day & -4.59 & $(-3.233)$ & $(-0.71 ; 0.48)$ & $(-0.50 ; 0.34)$ & -9.07 & $(-6.385)$ & $(-0.82 ; 0.83)$ & $(-0.58 ; 0.59)$ \\
\hline \multicolumn{9}{|l|}{ Peru - 2002} \\
\hline Less than US\$ 1 (PPP) a day & -0.23 & $(-0.209)$ & $(0.00 ; 0.12)$ & $(0.00 ; 0.11)$ & -0.59 & $(-0.532)$ & $(0.00 ; 0.15)$ & $(0.00 ; 0.14)$ \\
\hline Less than US\$2 (PPP) a day & 0.08 & $(0.070)$ & $(-0.08 ; 0.16)$ & $(-0.07 ; 0.14)$ & 0.16 & $(0.147)$ & $(-0.07 ; 0.23)$ & $(-0.06 ; 0.21)$ \\
\hline
\end{tabular}

Source: Author's calculations based on Household Surveys for each country. Poverty lines are 1 and 2 dollars respectively, expressed at PPP values.

Note: $95 \%$ confidence interval for columns using imputed non-remittances income. 
Panel A. (\% of GDP)

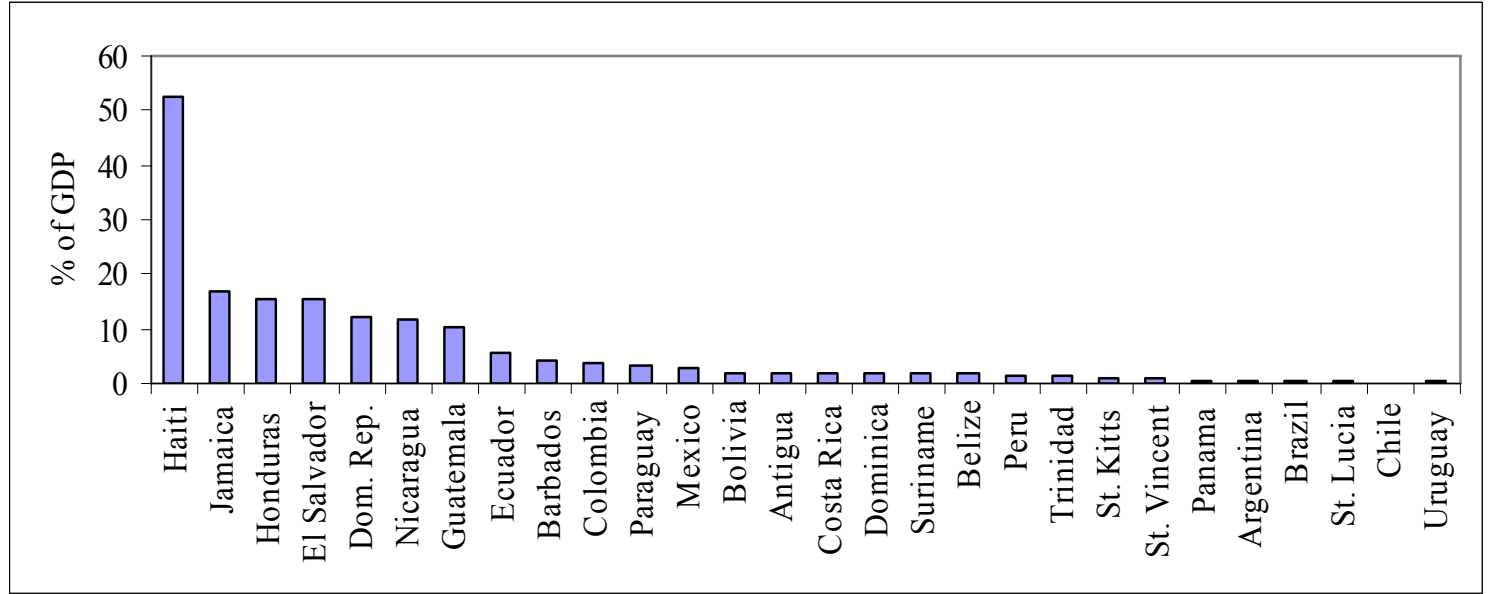

Panel B. (US\$ millions)

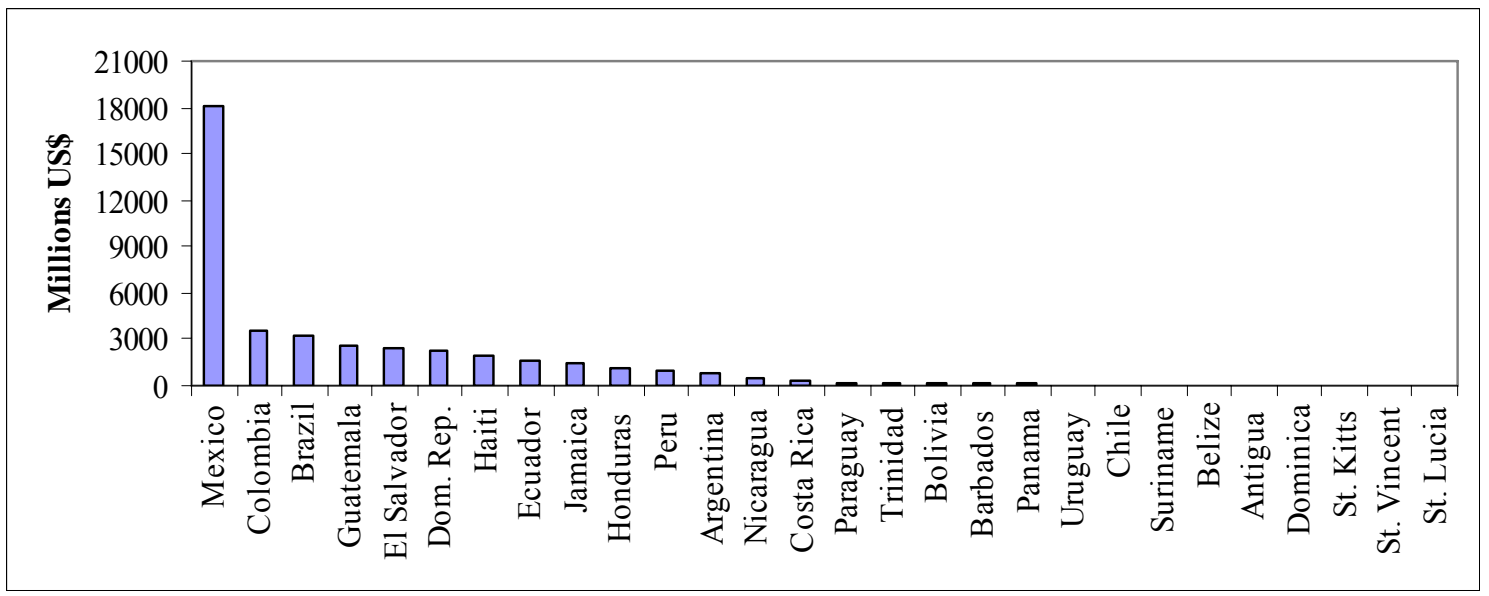

Source: Own calculations using IMF, World Economic Outlook Database. 